\title{
Factors associated with smoking in immigrants from non-western to western countries - what role does acculturation play? A systematic review
}

\author{
Katharina Reiss ${ }^{*}$, Jessica Lehnhardt and Oliver Razum
}

\begin{abstract}
Introduction: We aimed to identify factors associated with smoking among immigrants. In particular, we investigated the relationship between acculturation and smoking, taking into consideration the stage of the 'smoking epidemic' in the countries of origin and host countries of the immigrants.

Methods: We searched PubMed for peer-reviewed quantitative studies. Studies were included if they focused on smoking among adult immigrants (foreign-born) from non-western countries now residing in the USA, Canada, Ireland, Germany, the Netherlands, Norway, the UK, and Australia. Studies were excluded if, among others, a distinction between immigrants and their (native-born) offspring was not made.

Results: We retrieved 27 studies published between 1998 and 2013. 21 of the 27 studies focused on acculturation (using bidimensional multi-item scales particularly designed for the immigrant group under study and/or proxy measures such as language proficiency or length of stay in host country) and 16 of those found clear differences between men and women: whereas more acculturated women were more likely to smoke than less acculturated women, the contrary was observed among men.

Conclusion: Immigrants' countries of origin and host countries have reached different stages of the 'smoking epidemic' where, in addition, smoking among women lags behind that in men. Immigrants might 'move' between the stages as (I) the (non-western) countries of origin tend to be in the early phase, (II) the (western) host countries more in the advanced phase of the epidemic and (III) the arrival in the host countries initiates the acculturation process. This could explain the 'imported' high (men)/low (women) prevalence among less acculturated immigrants. The low (men)/high (women) prevalence among more acculturated immigrants indicates an adaptation towards the social norms of the host countries with ongoing acculturation.
\end{abstract}

Keywords: Systematic review, Immigrants, Smoking, Acculturation, Smoking epidemic

\section{Introduction}

High-income or economically developed western countries, such as North America, North and West Europe, Australia, and New Zealand are characterised by considerable ethnic diversity. The immigrant populations residing in western societies are heterogeneous, comprising people from different countries of origin, with different motivations to migrate, cultural identities etc. Health outcomes among immigrants in terms of mortality and

\footnotetext{
*Correspondence: katharina.reiss@uni-bielefeld.de

Department of Epidemiology \& International Public Health, Bielefeld School of Public Health (BiSPH), Bielefeld University, P.O. Box 1001 31, 33501 Bielefeld, Germany
}

morbidity have been largely covered in international research. Fewer studies focused on immigrants' health behaviour and especially on the determinants of health behaviour such as smoking. Smoking is one of the leading causes for premature death and thus a particularly risky health behaviour. It causes a variety of cancers and cardiovascular diseases [1-4]. On the individual level, smoking patterns vary with socioeconomic status - and here especially with education - with stress, age, and gender. Smoking is also influenced by peer group social norms on the interpersonal level and country-specific tobacco control interventions (public and work place 
bans, cigarette prices etc.) or the society's social support system of smoking on the socio-political level [5-15].

Smoking behaviour as well as norms and attitudes towards smoking also differ between countries. Lopez et al. [16] speak of the 'smoking epidemic', a four-stage model describing the progress of smoking among men and women: in the $1^{\text {st }}$ stage smoking predominantly involves men. In the $2^{\text {nd }}$ stage, smoking prevalence increases steeply among men and slightly among women. The $3^{\text {rd }}$ stage is characterised by a further increase in smoking among women. Smoking among men starts declining and prevalences among men and women converge. The $4^{\text {th }}$ stage shows a further decline in prevalence among both men and women (see Figure 1). Rather than looking at the stages as isolated parts, the model should be understood as a process or continuum over decades [17]. Whereas economically developed western countries are in the advanced phases of the epidemic, countries such as China, India, Syria or some Southeast Asian or African countries are more located towards the beginning or early phases of the epidemic [18-22].

Thus, immigrants from non-western to western countries move from an earlier to a more advanced stage of the epidemic. As health risks and resources they acquired in their countries of origin are not static and may be subject to change in the host countries, immigrants might adapt to, for example, the host country's smoking behaviour [23]. This change in smoking behaviour might be the result of an acculturation process which starts immediately after arrival in the host country. Acculturation is a complex phenomenon: it refers to a dynamic process through which behaviours of immigrants change as a result of interactions with individuals in their (new) social and cultural environment [24]. The concept of acculturation can be either understood as unidimensional - where immigrants move along a continuum ranging from a weak adaptation to the host culture to a strong one - or as bidimensional - where immigrants may independently maintain the culture of origin and adapt to the host culture. The best known bidimensional acculturation model was developed by Berry [25], although recent research activities propose a more extensive approach to acculturation. Schwartz et al. [26], for example, also incorporate cultural practices, such as customs and traditions, cultural values, such as individualism or independence and a cultural identification, such as the attachment to a certain cultural group. It becomes apparent that acculturation is influenced by three main contextual areas: the context prior to immigration, the immigration context itself and the settlement context [27].

Acculturation models are widely used in health behaviour research with various measures, ranging from indirect proxy measures (e.g. time spent in host country, or proficiency in the language of the host country), to multi-item scales [27-30]. The relationship between acculturation and, for example, substance abuse, dietary practices, leisure-time activity or health services use has mainly been studied in the United States [31-38]. There is also evidence from the US linking smoking behaviour to level of acculturation [39-45]. In Europe, research on this relationship is scarce - smoking among immigrants has been investigated mainly with regard to the association between smoking and socioeconomic status.

A combination of the 'smoking epidemic' model and the acculturation model should allow to predict the smoking behaviour of immigrants: populations that migrate from non-western to western countries will 'bring along' the smoking behaviour from their countries of origin and maintain it for some time after migration. With the commencing acculturation process in the host

Smoking prevalence

among adults (in \%)

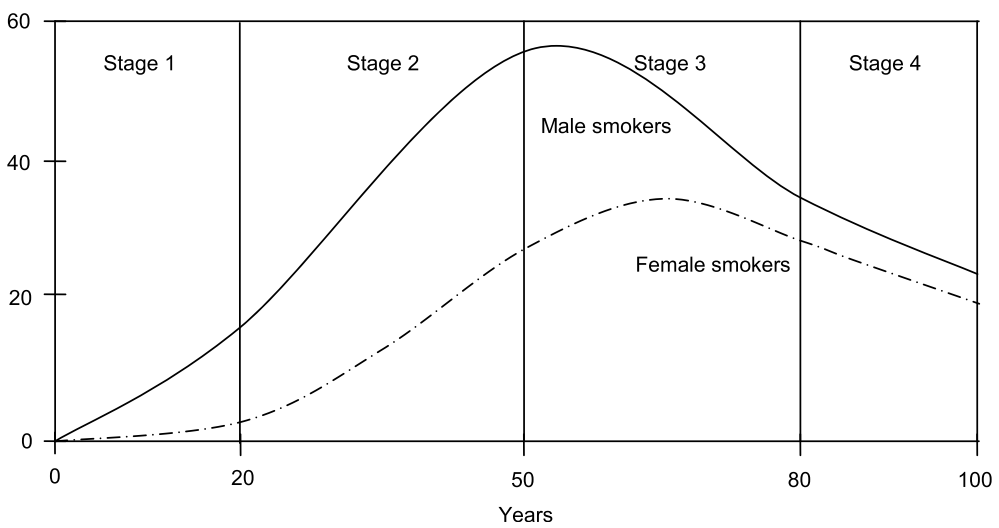

Figure 1 The stages of the 'smoking epidemic' proposed by Lopez et al. in 1994. 
countries, these 'imported' risks will change and immigrants will adapt to the smoking behaviour of the majority population in the host country (see Figure 2). This assumes that acculturation is an important (albeit not necessarily the only) determinant of smoking behaviour among immigrants.

The aim of this paper is to identify common patterns for smoking behaviour among immigrants (or foreignborn persons) from non-western to western countries with a special focus on the role of acculturation through a systematic review over the international literature.

\section{Methods}

\section{Search strategy}

The database PubMed was searched in May 2012 and again in March 2014 using the MeSH terms displayed in Figure 3. All studies were filtered first by title and then by a narrower filter procedure following the inclusion and exclusion criteria listed below. Next, all full-texts of the remaining articles were read and then entered for the review or dropped. Additionally, the reference lists of included articles were scanned for studies that were not detected by the database search.

\section{Eligibility criteria}

All peer-reviewed primary studies in English language published after 1990 were included. Studies were included if they matched the following criteria: quantitative study; analysis of factors associated with cigarette smoking (irrespective of frequency and quantity); focus on immigrant adults (18 years and older); specification of country of origin; personal migration experience from an economically developing non-western country of origin to an economically developed western host country (North America, North and West Europe, Australia, and New Zealand). Studies that focused on foreign- and native-born persons were included if the proportion of immigrants or foreign-born persons was more than $90 \%$. Studies with less than $90 \%$ were only included if a clear distinction between foreign- and native-born persons was made and factors associated with smoking were examined and presented separately for each group.

Studies were excluded if no distinction between immigrants (foreign-born) and their offspring (born in the host country) was made, if the immigrant group under study was defined by a specific characteristic (e.g. pregnancy, occupation, addiction etc.); if the study focused

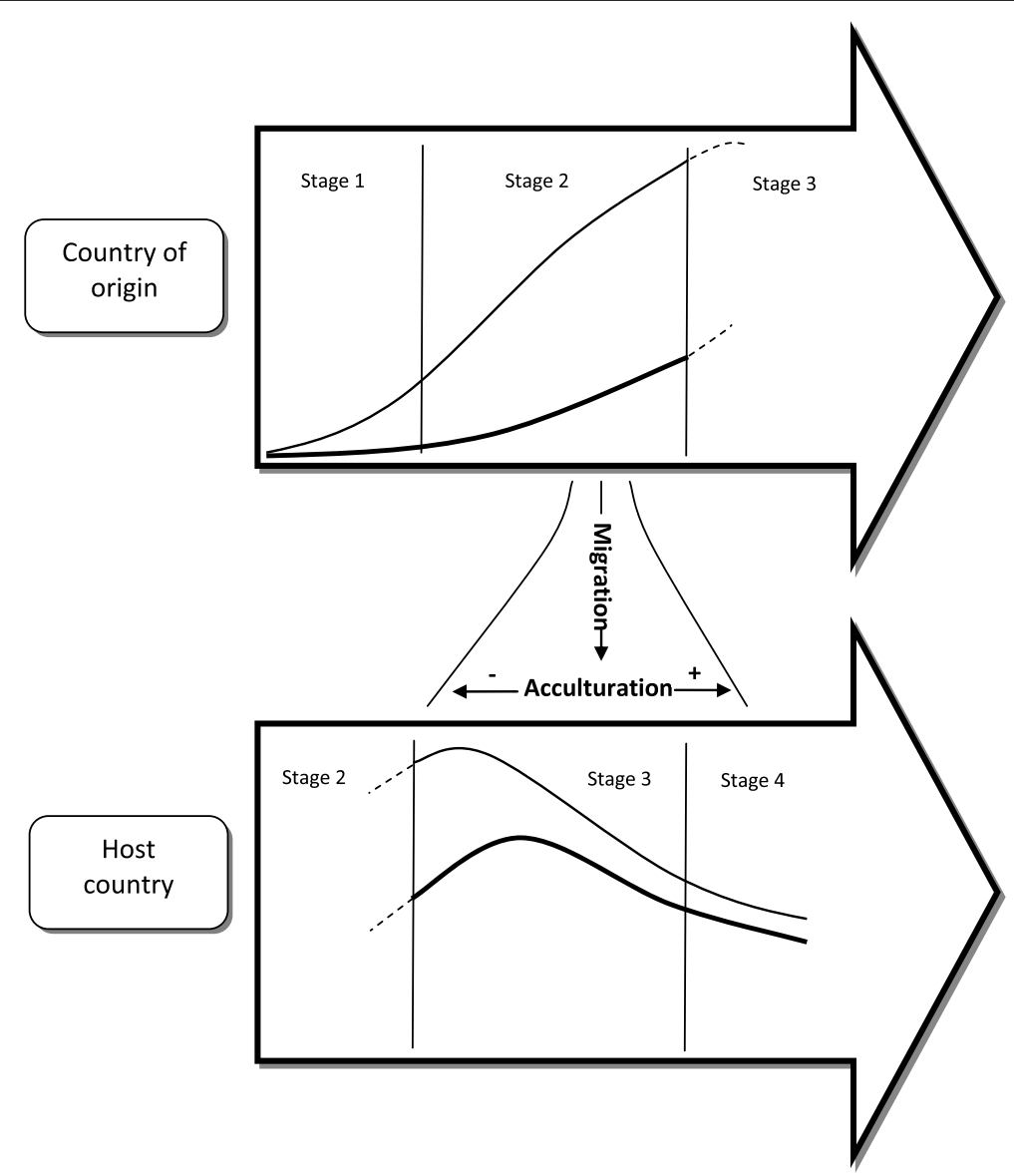

Figure 2 Schematic diagram on the association between the 'smoking epidemic' and acculturation. 


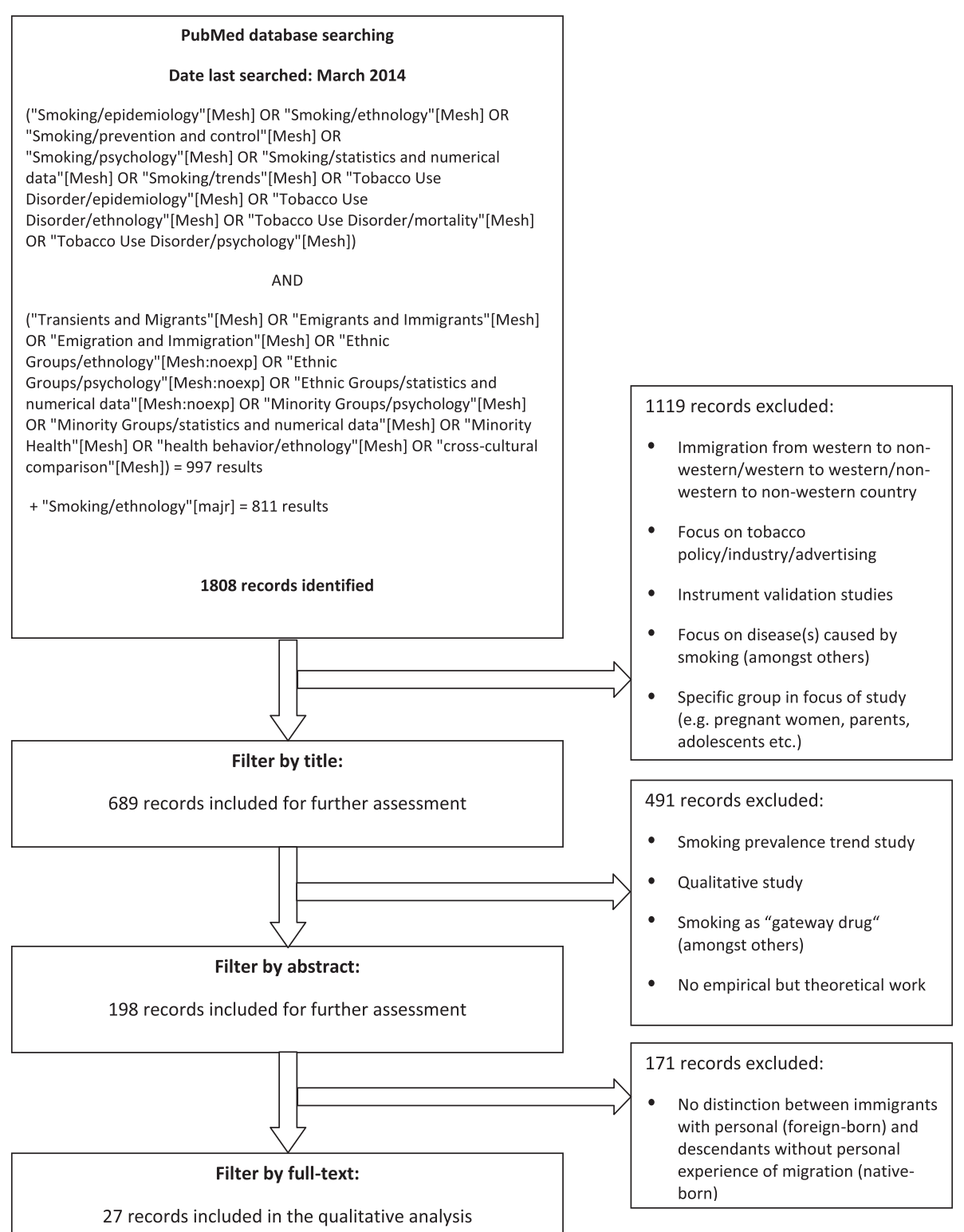

Figure $\mathbf{3}$ Inclusion and exclusion of publications in the systematic review.

on risk factors for (or causes of) certain diseases, was not empirical but theoretical, merely investigated time trends in smoking prevalence, focused on any form of drug intake or any form of tobacco use other than smoking cigarettes, was conducted for validating a questionnaire, evaluated a prevention programme or focused on media/advertisement influence on smoking behaviour.

\section{Synthesis of results}

The results reported in the articles were included as findings in this review if they were derived from any form of statistical analysis, regardless of whether descriptive analyses or regression models. For example, variables which were not significantly associated with smoking in simple regression analyses might have not been included in the subsequent multiple regression analyses. As non-significance does not equate with non-relevance, all factors known to be relevant were covered in this review. In the case of conflicting results between descriptive and analytical procedures, those derived from the highest level of statistical analysis were counted as finding. A metaanalysis was not performed as definitions and measurements of the variables of interest were not consistent between the studies.

The retrieval procedure was performed independently by two investigators. By the end of the first retrieval 
round, there were five articles with conflicting decisions regarding inclusion. After discussion, four articles were excluded and one was included in the review. After the second search there were no discrepancies. The final number of studies included was 27. The retrieval procedure and the criteria for exclusion and inclusion are outlined in Figure 3.

The two investigators also independently assessed and documented methodological quality of the studies to trace possible bias within as well as across the studies. The following information was documented for each study: aim, definition of the immigrant group, data source (if secondary data was used) or sampling procedure (if primary data was generated), method of data collection, study design, number of immigrant participants, statistical methods applied, operational definition of dependent and independent variables, and limitations reported.

\section{Results}

\section{Study characteristics}

The 27 studies included were published between 1998 and 2013 and all of them used a cross-sectional design; the majority (19 of 27) were conducted in the USA; two were conducted in Germany, and one each in Ireland, Canada, the Netherlands, the UK, Norway, and Australia. Most of the studies focused on Asian immigrants, originating from China (5 of 27), Korea (3 of 27), Vietnam (2 of 27), and the Philippines (1 of 27). Three studies investigated more than one Asian immigrant group. The second-largest immigrant group under study were Latinos/Hispanics from Mexico (2 of 27) and El Salvador (1 of 27). One study focused on African immigrants. One study compared the smoking behaviour between Asians and Latinos/Hispanics among others. Two studies focused on Arabs. One study each investigated smoking among Ethiopians, Polish immigrants, Turkish immigrants, and immigrants from the former Soviet Union; and two studies focused on more than one immigrant group. The sample sizes ranged from 96 to 16,738 persons. Eleven studies had a sample size below 1,000 , in ten studies the sample size ranged from 1,000-5,000 participants and six studies surveyed more than 5,000 persons. Fifteen of 27 studies focused on foreign-born persons only, in seven studies more than $90 \%$ were foreignborn, in five studies between $7 \%$ and $77 \%$ of the participants were foreign-born. Four studies restricted their study sample to men and five studies performed their highest statistical analysis only for men as the number of female smokers was too small. Eleven of 27 studies stratified their analysis by gender, seven adjusted for gender.

\section{Study findings}

Table 1 presents contextual information of the different countries, such as the GDP per capita as prosperity indicator and the smoking prevalence in the immigrants' host countries, their countries of origin and among immigrants themselves as reported by the studies included: smoking prevalence among men in the countries of origin is higher than that among men in immigrants' host countries, whereas the contrary applies to women. Additionally, the gap in smoking prevalence between men and women is larger in the countries of origin than in the host countries. Among immigrants, this genderdifference is not as large as in their countries of origin but still larger than in the host countries.

Table 2 presents the factors associated with smoking among immigrants, for men and women combined if analyses were only adjusted for gender or no genderspecific differences were observed; or for men and women separately if gender-specific differences were observed or analyses were restricted to one gender only.

Acculturation was focused on in 21 of all 27 studies. Table 3 illustrates the different acculturation measures used. Only five studies applied multi-item acculturation scales that were developed particularly for the immigrant group under study and were based on a bidimensional concept of acculturation. Multiple questions were used to identify the preference for and the fluency in the culture of the country of origin or the host country. Higher scores on the scales reflected an orientation more towards the host country culture. All other studies used proxy measures for acculturation, mainly proficiency in the language of the host country and length of stay. The majority of the studies (16 of 21) that included acculturation emphasised differences by gender, irrespective of the acculturation measure applied (acculturation scale or proxy measure for acculturation): less acculturated men (or men with lower language proficiency or short length of stay) had higher smoking prevalences than more acculturated men (or men with higher language proficiency or long length of stay). However, the contrary applied to women. Women with a lower level of acculturation (or lower language proficiency or short length of stay) had lower smoking prevalences than women with a higher acculturation level (or higher language proficiency or long length of stay). These gender-specific patterns were observed both in studies that explicitly stated that they used proxy variables to measure acculturation (11 of 21) and in studies that did not link variables such as length of stay or language proficiency to acculturation (5 of 21).

Gender was one of the factors most frequently reported to be associated with smoking behaviour in immigrants (23 of 27). The majority of the studies reported marked differences by gender, with men being more likely to be current smokers than women. 
Table 1 Comparison of Gross Domestic Product (GDP) per capita (US\$), and smoking prevalence in countries of origin, host countries and among immigrants

\begin{tabular}{|c|c|c|c|c|}
\hline $\begin{array}{l}\text { Country of origin of } \\
\text { immigrants }\end{array}$ & $\begin{array}{l}\text { GDP per capita (US\$, 2012) } \\
\text { in country of origin }{ }^{1}\end{array}$ & $\begin{array}{l}\text { Smoking prevalence in } \\
\text { country of origin in } 2011^{2}\end{array}$ & $\begin{array}{l}\text { Smoking prevalence among } \\
\text { immigrants according to studies } \\
\text { included in the review }\end{array}$ & $\begin{array}{l}\text { Study reporting the } \\
\text { smoking prevalence } \\
\text { among immigrants }\end{array}$ \\
\hline \multicolumn{5}{|c|}{ Host country: United States of America | GDP per capita (US\$, 2012): 51,749 | Smoking prevalence (2011): Men 21\%, Women 17\% } \\
\hline \multirow[t]{15}{*}{ China } & 6,091 & Men: $47 \%$ & Men: $16 \%$ & 2 \\
\hline & & Women: $2 \%$ & Women: $7 \%$ & \\
\hline & & & Men: 14\% & 7 \\
\hline & & & Women: 6\% & \\
\hline & & & Men: 18\% & 11 \\
\hline & & & Women: 4\% & \\
\hline & & & Men: $25 \%$ & 12 \\
\hline & & & Women: 3\% & \\
\hline & & & Men: 15\% & 6 \\
\hline & & & Women: 4\% & \\
\hline & & & Men: 34\% & 15 \\
\hline & & & Women:2\% & \\
\hline & & & Total: $24 \%$ & 14 \\
\hline & & & $\mathrm{Hmong}^{4}$ men: $12 \%$ & 1 \\
\hline & & & Hmong ${ }^{4}$ women: $1 \%$ & \\
\hline \multirow[t]{3}{*}{ Cambodia } & 945 & Men: $42 \%$ & Men: 14\% & 1 \\
\hline & & Women: 3\% & Women: 2\% & \\
\hline & & & Total: 42\% & 14 \\
\hline \multirow[t]{2}{*}{ Laos } & 1,412 & Men: 48\% & Men: 32\% & 1 \\
\hline & & Women: 4\% & Women: 4\% & \\
\hline \multirow[t]{8}{*}{ Republic of Korea } & 22,590 & Men: 49\% & Men: $32 \%$ & 10 \\
\hline & & Women: 8\% & Women: 4\% & \\
\hline & & & Men: 39\% & 16 \\
\hline & & & Women: 7\% & \\
\hline & & & Men: $37 \%$ & 6 \\
\hline & & & Women: 9\% & \\
\hline & & & Men: 27\% & 13 \\
\hline & & & Total: 27\% & 14 \\
\hline \multirow[t]{7}{*}{ Vietnam } & 1,755 & Men: 46\% & Men: 42\% & 1 \\
\hline & & Women: 2\% & Women: 1\% & \\
\hline & & & Men: $32 \%$ & 6 \\
\hline & & & Women: 2\% & \\
\hline & & & Men: $32 \%$ & 8 \\
\hline & & & Men: 43\% & 19 \\
\hline & & & Total: 40\% & 14 \\
\hline \multirow[t]{5}{*}{ Philippines } & 2,587 & Men: 44\% & Men: 35\% & 5 \\
\hline & & Women: 10\% & Men: 24\% & 7 \\
\hline & & & Women: 10\% & \\
\hline & & & Men: 25\% & 6 \\
\hline & & & Women: 8\% & \\
\hline
\end{tabular}


Table 1 Comparison of Gross Domestic Product (GDP) per capita (US\$), and smoking prevalence in countries of origin, host countries and among immigrants (Continued)

\begin{tabular}{|c|c|c|c|c|}
\hline \multirow[t]{6}{*}{ Mexico } & 9,749 & Men: 27\% & Men: 33\% & 4 \\
\hline & & Women: 8\% & Women: 11\% & \\
\hline & & & Men: 29\% & 9 \\
\hline & & & Women: 10\% & \\
\hline & & & Hispanic ${ }^{5}$ men: 20\% & 7 \\
\hline & & & Hispanic ${ }^{5}$ women: $8 \%$ & \\
\hline \multirow[t]{4}{*}{ El Salvador } & 3,790 & Men: 24\% & Men: $20 \%$ & 17 \\
\hline & & Women: 3\% & Women: 3\% & \\
\hline & & & Hispanic $^{5}$ men: 20\% & 7 \\
\hline & & & Hispanic ${ }^{5}$ women: $8 \%$ & \\
\hline \multirow[t]{2}{*}{ Sub-Saharan Africa ${ }^{3}$} & 1,417 & Men: $22 \%$ & Men: $22 \%$ & 18 \\
\hline & & Women: 4\% & Women: 7\% & \\
\hline \multirow[t]{2}{*}{ Arab world ${ }^{3}$} & 7,048 & Men: 37\% & Men: $60 \%$ & 3 \\
\hline & & Women: 4\% & Women: 11\% & \\
\hline \multirow[t]{2}{*}{ South $\mathrm{Asia}^{3}$} & 1,398 & Men: $36 \%$ & Men: $16 \%$ & 6 \\
\hline & & Women: $8 \%$ & Women: 3\% & \\
\hline \multicolumn{5}{|c|}{ Host country: Canada GDP per capita (US\$, 2012): 52,219 Smoking prevalence (2011): Men 20\%, Women: $15 \%$} \\
\hline \multirow[t]{2}{*}{ Ethiopia } & 454 & Men: $8 \%$ & Men: $28 \%$ & 20 \\
\hline & & Women: $<1 \%$ & Women: 10\% & \\
\hline \multicolumn{5}{|c|}{ Host country: Germany GDP per capita (US\$, 2012): 41,863 Smoking prevalence (2011): Men 35\%, Women: $25 \%$} \\
\hline \multirow[t]{2}{*}{ Former Soviet Union ${ }^{3}$} & 9,464 & Men: $44 \%$ & Men: $37 \%$ & 22 \\
\hline & & Women: $11 \%$ & Women: $16 \%$ & \\
\hline \multirow[t]{2}{*}{ Turkey } & 10,666 & Men: $42 \%$ & Men: 49\% & 23 \\
\hline & & Women: 13\% & Women: 28\% & \\
\hline \multicolumn{5}{|c|}{ Host country: Ireland ${ }^{6}$ GDP per capita (US\$, 2012): 45,932 Smoking prevalence (2011): Men 23\%, Women: $20 \%$} \\
\hline \multirow[t]{2}{*}{ Poland } & 12,708 & Men: $38 \%$ & Men: $51 \%$ & 21 \\
\hline & & Women: $27 \%$ & Women: 40\% & \\
\hline \multicolumn{5}{|c|}{ Host country: Australia GDP per capita (US\$, 2012): 67,556 Smoking prevalence (2011): Men 21\%, Women: 19\% } \\
\hline \multirow[t]{2}{*}{$\overline{\text { Arab world }^{3}}$} & 7,048 & Men: $37 \%$ & Men: $44 \%$ & 27 \\
\hline & & Women: 4\% & Women: $23 \%$ & \\
\hline \multicolumn{5}{|c|}{ Host country: The Netherlands GDP per capita (US\$, 2012): 45,955 Smoking prevalence (2011): Men 29\%, Women: 23\% } \\
\hline \multirow[t]{2}{*}{ Turkey } & 10,666 & Men: 42\% & Men: $63 \%$ & 24 \\
\hline & & Women: 13\% & Women: 32\% & \\
\hline \multirow[t]{2}{*}{ Morocco } & 2,902 & Men: $32 \%$ & Men: $30 \%$ & 24 \\
\hline & & Women: $2 \%$ & Women: $1 \%$ & \\
\hline \multirow[t]{2}{*}{ Suriname } & 9,376 & Men: $17 \%$ & Men: $55 \%$ & 24 \\
\hline & & Women: 3\% & Women: 30\% & \\
\hline \multicolumn{5}{|c|}{ Host country: Norway GDP per capita (US\$, 2012): 99,558 Smoking prevalence (2011): Men 28\%, Women: $26 \%$} \\
\hline \multirow[t]{2}{*}{ Turkey } & 10,666 & Men: 42\% & Men: $56 \%$ & 25 \\
\hline & & Women: 13\% & Women: 28\% & \\
\hline \multirow[t]{2}{*}{ Iran } & 6,816 & Men: $26 \%$ & Men: $42 \%$ & 25 \\
\hline & & Women: $1 \%$ & Women: 23\% & \\
\hline \multirow[t]{2}{*}{ Pakistan } & 1,257 & Men: 38\% & Men: $34 \%$ & 25 \\
\hline & & Women: 7\% & Women: 4\% & \\
\hline
\end{tabular}


Table 1 Comparison of Gross Domestic Product (GDP) per capita (US\$), and smoking prevalence in countries of origin, host countries and among immigrants (Continued)

\begin{tabular}{|c|c|c|c|c|}
\hline \multirow[t]{2}{*}{ Vietnam } & 1,755 & Men: 46\% & Men: 36\% & 25 \\
\hline & & Women: 2\% & Women: 5\% & \\
\hline \multirow[t]{2}{*}{ Sri Lanka } & 2,923 & Men: 31\% & Men: 19\% & 25 \\
\hline & & Women: $1 \%$ & Women: 1\% & \\
\hline \multicolumn{5}{|c|}{ Host country: United Kingdom | GDP per capita (US\$, 2012): 39,093 | Smoking prevalence (2011): Men 22\%, Women: 22\% } \\
\hline \multirow[t]{2}{*}{ China } & 6,091 & Men: 47\% & Men: 24\% & 26 \\
\hline & & Women: $2 \%$ & Women: 1\% & \\
\hline
\end{tabular}

15ource: The World Bank - GDP per capita (currency US\$) 2012. URL: http://data.worldbank.org/indicator/NY.GDP.PCAP.CD.

${ }^{2}$ Source: WHO Report on the Global Tobacco Epidemic from 2013 (Ethiopia: 2011, Suriname: 2009). URL: http://www.who.int/tobacco/global_report/en/.

${ }^{3}$ As no measures are available for these aggregated geographical areas, GDP per capita was calculated as sum of GDP divided by sum of population of all countries, smoking prevalences were averaged across all countries.

${ }^{4} \mathrm{Hmong}$ people originate from many different Southeast Asian and East Asian countries. As most of them live in China, prevalences were assigned to China.

${ }^{5}$ Hispanic or Latino Americans originate from different Latin American countries or the Iberian Peninsula. As only immigrants from Mexico and El Salvador were investigated in the scope of this review, prevalences were assigned to each of both countries.

${ }^{6}$ Source: Health Service Executive: Cigarette Smoking Prevalence in Ireland 2013. URL: http://www.hse.ie/eng/about/Who/TobaccoControl/Research/.

${ }^{7}$ Studies are presented as numbers, further information on studies is specified in Table 4.

Additionally, educational level (19 of 27), age (9 of 27), employment (6 of 27), and marital status (7 of 27) were frequently reported. Younger and non-married persons were more likely to smoke than older and married persons. Smoking was positively associated with a low educational level among men but with a high educational level among women (11 of 27). In 4 out of 27 studies, employed persons had a higher smoking prevalence than unemployed persons. Other factors, such as income, religion, alcohol consumption or knowledge of tobacco health risks, were reported by less than five studies (see Table 2), and often only for men.

Quality assessment of the studies included for the review All studies presented a clear study aim, defined their study population accordingly and clearly specified dependent and independent variables. Besides descriptive analyses, logistic regression analyses were applied in 20 of 27 studies (see Table 4).

Concerning the sampling procedures of the studies generating primary data (19 of 27), the vast majority used a list-based (mainly a telephone list-based) technique with focus on names specific to the immigrant group or a community-orientated (via migrant organisations or networks) sampling strategy. It has to be noted that (I) a list-based approach is restricted to only those appearing on, for example, the telephone list, and (II) a random sample for a quantitative study can hardly be realised by using a community-orientated approach as it is highly likely to include predominantly socially integrated people.

A major part of the studies (18 of 27) applied both translated instruments and bilingual interviewers. Six studies reported either the use of translated instruments or the employment of bilingual interviewers. Two studies did not provide any information in this regard and one study was conducted in the host country language (English) only. Applying translated, culturally adapted, and validated instruments - especially on acculturation and smoking as well as bilingual interviewers may lower the risk of selection and information bias $[46,47]$. If, however, the risk of selection bias is high, the generalisability of the study results to a group other than the selected one is questionable (see Table 4).

Moreover, using self-reported data to assess smoking behaviour may lead to an under- or overestimation of the smoking status, for example, due to socially desirable responses. As all studies used self-reported data, information bias cannot be excluded. However, one study validated the self-reported data by using expired carbon monoxide measures and showed a significantly high correlation between self-reports and measurements. Furthermore, all studies applied a cross-sectional design. Here, factors associated with smoking and smoking status are measured simultaneously. Thus, it is neither possible to assess causal pathways between factors associated with smoking and smoking status nor to draw conclusions on changes over time. Additionally, as the sample in cross-sectional studies comprises different age or birth cohorts, the study findings may also be the result of a cohort effect.

\section{Discussion}

Our analysis shows that smoking among immigrants from economically developing non-western to economically developed western countries is positively associated with (I) a low acculturation level among men, (II) a high acculturation level among women - as measured by acculturation scales or proxy measures such as language proficiency or duration of stay - and in general (III) with being male, of younger age, non-married, and 
Table 2 Findings of the systematic review

Factors associated with smoking

Smoking was positively associated with the

Acculturation scale

Acculturation with main focus on the following proxy measures:

Proficiency in the language of host country ${ }^{\S}$

Length of stay in host country

Country of birth ${ }^{\S, \$}$

Gender

Educational level

Employment

Age

Income

Religion

Marital status

Self-assessed health status

Pre-migration life events

Post-migration life events

Social support

Alcohol consumption

Knowledge of tobacco risks

Knowledge of cancer warning signs
Proficiency in the language of host country

Length of stay in host country

Country of birth $\$$

Proficiency in the
language of host country
Length of stay in host
country
Country of birth
Country of smoking
initiation
Age at migration

Age at migration stated factor among

Men and Men Women
women

Low vs. high

High vs. low

Country of
origin vs. host
Young vs. old

Long vs. short

Low vs. high

Low vs. high

Low vs. high

Short vs. long

Foreign-born

vs. native-born

Studies reporting the association"

Native-born vs.

foreign-born

Being male

vs. female

Low vs. high

Low vs. high

No vs. yes

Yes vs. no

Yes vs. no

Young vs. old

Young vs. old

Low vs. high

Low vs. high

Not religious

vs. religious

Non-married

vs. married

Non-married

vs. married

Poor vs. good

Exposed vs.
non-exposed
No association

Satisfied vs.

not satisfied

Yes vs. no

Yes vs. no

Low vs. high/

moderate

No vs. yes
Native-born vs.

foreign-born

High vs. low

High vs. low

$1,10,12^{*}$

Long vs. short

$11^{*}, 7,5^{*}, 6,8^{*}, 19^{*}$

$13 *, 6$

7

9

High vs. low

$15^{*}, 16^{*}$

ong vs. short

$2^{*}, 16^{*}, 20,22,23$

18,23

All studies except for $5^{*}, 8^{*}, 13^{*}, 19^{*}$

$1,20,21,18,14,7,6,27$

High vs. low

$19^{*}, 5^{*}, 15^{*}, 16^{*}$, $2^{*}, 8^{*}, 4,22,23,24,25$

18,27

21,10

$11^{*}, 13^{*}$

$1,14,10,26,27$

$2^{*}, 13^{*}, 11^{*}, 19^{*}$

7,18

$5^{*}, 2^{*}$

$20,16^{*}$

$20,14,7,18,6,27$

$8^{*}$

27

Non-exposed vs. exposed

Exposed vs.

non-exposed

20

No association

6

$13^{*}, 8^{*}, 16^{*}$ 
Table 2 Findings of the systematic review (Continued)

\begin{tabular}{|c|c|c|}
\hline Perceived risk of smoking-related diseases & High vs. low & $5^{*}$ \\
\hline Blood check and/or physical checkup & No vs. yes & $8^{*}$ \\
\hline Source of health care & $\begin{array}{l}\text { Non-western } \\
\text { vs. western }\end{array}$ & $15^{*}$ \\
\hline Role model smoking & Yes vs. no & $19^{*}, 5^{*}$ \\
\hline Depression score & Higher vs. lower & $19^{*}$ \\
\hline Regular exercise & Less vs. more & $19^{*}$ \\
\hline Health insurance & $\begin{array}{l}\text { Not available } \\
\text { vs. available }\end{array}$ & $11^{*}, 19^{*}$ \\
\hline Geographical area of origin (in country of origin) & Rural vs. urban & $19^{*}$ \\
\hline
\end{tabular}

\#Studies are presented as numbers, further information on studies is specified in Table 4.

*Indicates studies that either restricted their highest statistical method or the study population in general to men only.

\$Only applicable to studies that investigated foreign- and native-born migrants.

${ }^{\S}$ Variables that were included in the studies without linking them to acculturation. Thus, the respective variable is listed separate from acculturation.

employed. Smoking was also associated with a low educational level among men and a high education among women.

Socio-economic and socio-demographic factors such as marital status, education, employment status, age, and gender are already known to determine smoking in any population group, irrespective of their migration status. Among immigrants, acculturation is an additional factor linked to smoking. One possible explanation can be found in the transition brought about by the immigration from non-western to western countries, which occupy different positions in the 'smoking epidemic'. Western countries tend to be located towards the advanced phases of the epidemic, whereas non-western countries tend to be located more towards the early phases, and smoking among women tends to lag behind that in men $[48,17]$. This is supported by higher prevalences among men from non-western countries compared to men from western countries, lower prevalences among women from non-western countries compared to women from western countries and by the large gap in smoking between men and women from non-western countries as seen in Table 1. It is compatible with the hypothesis that with the immigration from non-western to western countries immigrant men and women may 'import' their smoking behaviour from the country of origin to the host country. If acculturation is regarded as process which starts with the immigration to the host country, this might explain the high smoking prevalence among less acculturated men and the low smoking prevalence among less acculturated women. Furthermore, with increasing duration of stay in the host country, immigrants might 'move' towards the advanced phases of the smoking epidemic and adapt to the smoking behaviour of the host country. This is likely to be the result of an ongoing acculturation process. In many nonwestern countries smoking is still uncommon and socially unacceptable among women but highly acceptable among men [42-45]. This pattern of social support of smoking might account for the smoking behaviour among recent immigrants. In western societies smoking is equally accepted among men and women [42-45]. Immigrants might identify with these values and attitudes and adopt them in the course of the acculturation process towards a higher smoking prevalence among women and a lower one among men. These findings correspond well to the 'operant model of acculturation' as proposed by Landrine \& Klonoff [49]. It predicts that health behaviours with a high prevalence among initially low-acculturated immigrants will decrease in prevalence with increasing acculturation, whereas health behaviours with a low prevalence among low-acculturated immigrants will become more common with advancing acculturation. This model has already been successfully applied to health behaviours such as smoking, diet, alcohol use, and exercise $[49,50]$. The phenomenon that higher levels of acculturation are associated with increases in unfavourable health behaviours is also known as the immigrant paradox'.

Only few studies so far have explicitly focused on the relationship between acculturation and the stages of the 'smoking epidemic'; the studies investigating the course of the epidemic among immigrants have mainly focused on its association with educational level [51,52]. In general, research on smoking behaviour among immigrants with focus on acculturation is in its infancy in Europe. Only one of the European studies included in this review explicitly stated that it also measured acculturation.

However, this should not divert from the fact that, besides acculturation, there are several other determinants of smoking on the individual, cultural, economic and political level. There might also be interactions between certain determinants (e.g. between education and employment status). Differences between countries of origin and host countries regarding, for example, cigarette prices or bans on smoking in public/work places might additionally affect smoking in immigrants. 
Table 3 Acculturation measures used in the studies included for the review

\begin{tabular}{|c|c|c|c|}
\hline Study* & Acculturation measure (proxy variable) & $\begin{array}{l}\text { Were proxy measures } \\
\text { explicitly used to measure } \\
\text { acculturation? }\end{array}$ & Acculturation measure (scale) \\
\hline 1 & $\begin{array}{l}\text { Primary language, percentage of life lived } \\
\text { in USA }\end{array}$ & Yes & $\begin{array}{l}\text { Community and acculturation identification measure } \\
\text { ( } 21 \text { items); two main constructs: cultural fluency and } \\
\text { cultural orientation (to assess country of origin or US identification) }\end{array}$ \\
\hline 2 & Length of stay & No & \\
\hline 3 & & & $\begin{array}{l}\text { MAAS scale (Male Arab-American Acculturation) ( } 8 \text { items); } \\
\text { two main constructs: separation and assimilation \& integration } \\
\text { and marginalisation }\end{array}$ \\
\hline 4 & Country of smoking initiation & Yes & \\
\hline 5 & $\begin{array}{l}\text { Length of stay, self-perceived ethnic/cul- } \\
\text { tural identity, language proficiency (English, } \\
\text { Tagalog) }\end{array}$ & Yes & \\
\hline 6 & $\begin{array}{l}\text { English language used at home, length of } \\
\text { stay }\end{array}$ & Yes & \\
\hline 7 & $\begin{array}{l}\text { English language proficiency, length of } \\
\text { stay, country of birth }\end{array}$ & Yes & \\
\hline 8 & $\begin{array}{l}\text { English language proficiency, language } \\
\text { used at home, language used with friends, } \\
\text { length of stay }\end{array}$ & Yes & \\
\hline 9 & $\begin{array}{l}\text { Age at migration, country of birth, country } \\
\text { of smoking initiation }\end{array}$ & Yes & Bidimensional Acculturation Scale for Hispanics (4 items) \\
\hline 10 & & & $\begin{array}{l}\text { The Suinn-Lew Asian self-identity acculturation to US society } \\
\text { scale (education and length of stay added here) }\end{array}$ \\
\hline 11 & $\begin{array}{l}\text { English language used at home, reading of } \\
\text { English newspapers }\end{array}$ & Yes & \\
\hline 12 & & & $\begin{array}{l}\text { Linguistic acculturation scale for Southeast Asians ( } 7 \text { items); } \\
\text { two main constructs: English language proficiency, } \\
\text { Chinese language proficiency }\end{array}$ \\
\hline 13 & Length of stay & Yes & \\
\hline 14 & Legal immigrant status, length of stay & No & \\
\hline 15 & English language proficiency & No & \\
\hline 16 & $\begin{array}{l}\text { Length of stay, English language } \\
\text { proficiency }\end{array}$ & No & \\
\hline 17 & Length of stay, age at migration & Yes & \\
\hline 18 & Length of stay, country of birth & No & \\
\hline 19 & English language proficiency & Yes & \\
\hline 20 & Length of stay & No & \\
\hline 21 & Length of stay & No & \\
\hline 22 & Length of stay & No & \\
\hline 23 & Length of stay, country of birth & No & \\
\hline \multirow[t]{2}{*}{24} & $\begin{array}{l}\text { Social contacts with the host population, } \\
\text { years of immigration }\end{array}$ & Yes & \\
\hline & $\begin{array}{l}\rightarrow \text { only used to characterise the study } \\
\text { population, no further consideration }\end{array}$ & & \\
\hline \multirow[t]{2}{*}{25} & $\begin{array}{l}\text { Years lived in host country before age of } \\
16\end{array}$ & No & \\
\hline & $\begin{array}{l}\rightarrow \text { only used to characterise the study } \\
\text { population, no further consideration }\end{array}$ & & \\
\hline 26 & None & & \\
\hline 27 & None & & \\
\hline
\end{tabular}

${ }^{*}$ Studies are presented as numbers, further information on studies is specified in Table 4. 
Table 4 Methodological quality assessment of the articles included in the review

\begin{tabular}{|c|c|c|c|c|c|c|c|c|c|c|c|}
\hline No. & Authors & $\begin{array}{l}\text { Year and } \\
\text { country of } \\
\text { study }\end{array}$ & Study aim & $\begin{array}{l}\text { Immigrant } \\
\text { group under } \\
\text { study (definition } \\
\text { of immigrants) }\end{array}$ & $\begin{array}{l}\text { Data source } \\
\text { (secondary data) } \\
\text { or sampling } \\
\text { method (primary } \\
\text { data) }\end{array}$ & $\begin{array}{l}\text { Data } \\
\text { collection } \\
\text { method }\end{array}$ & $\begin{array}{l}\text { Study } \\
\text { design }\end{array}$ & $\begin{array}{l}\text { Number of } \\
\text { immigrant } \\
\text { participants }\end{array}$ & $\begin{array}{l}\text { Operational } \\
\text { definition of } \\
\text { variables used } \\
\text { (DV = dependent } \\
\text { variable; IV = } \\
\text { independent } \\
\text { variable) }\end{array}$ & $\begin{array}{l}\text { Statistical } \\
\text { methods } \\
\text { applied } \\
\text { besides } \\
\text { standard } \\
\text { descriptive } \\
\text { analyses }\end{array}$ & $\begin{array}{l}\text { Reported study } \\
\text { limitations }\end{array}$ \\
\hline 1 & $\begin{array}{l}\text { Constantine, } \\
\text { Rockwood, } \\
\text { Schillo, Alesci, } \\
\text { Foldes, Phan, } \\
\text { Chhith, Saul [56] }\end{array}$ & $\begin{array}{l}2010 \text { in } \\
\text { USA }\end{array}$ & $\begin{array}{l}\text { To explore } \\
\text { relationship } \\
\text { between smoking } \\
\text { and acculturation }\end{array}$ & $\begin{array}{l}\text { Hmong, } \\
\text { Vietnamese, } \\
\text { Cambodian and } \\
\text { Laotian } \\
\text { Americans } \\
\text { (country of birth, } \\
\text { self-identification) }\end{array}$ & $\begin{array}{l}\text { Sample } \\
\text { construction via list } \\
\text { of surnames } \\
\text { common to } \\
\text { specific } \\
\text { community, } \\
\text { utilization of } \\
\text { telephone screener } \\
\text { for recruitment } \\
\text { where a household } \\
\text { member was } \\
\text { selected at } \\
\text { random }\end{array}$ & $\begin{array}{l}\text { Interviewer- } \\
\text { and } \\
\text { telephone- } \\
\text { administered } \\
\text { survey (trans- } \\
\text { lated instru- } \\
\text { ment, bilin- } \\
\text { gual } \\
\text { interviewers) }\end{array}$ & $\begin{array}{l}\text { Cross- } \\
\text { sectional }\end{array}$ & $\begin{array}{l}1,615(95 \% \\
\text { foreign- } \\
\text { born) }\end{array}$ & $\begin{array}{l}\text { DV: current smoker } \\
\text { vs. non-smoker IV: } \\
\text { age, education, \% } \\
\text { of life lived in USA, } \\
\text { acculturation }\end{array}$ & $\begin{array}{l}\text { Logistic } \\
\text { regression } \\
\text { Stratified by } \\
\text { gender, for } \\
\text { males also by } \\
\text { nativity }\end{array}$ & $\begin{array}{l}\text { Self-reported } \\
\text { tobacco use, } \\
\text { underreporting of } \\
\text { smoking among } \\
\text { Vietnamese, } \\
\text { Cambodian, and } \\
\text { Lao populations } \\
\text { possible, small } \\
\text { sample size for } \\
\text { within group } \\
\text { (ethnicity and } \\
\text { gender) analysis }\end{array}$ \\
\hline 2 & $\begin{array}{l}\text { Hu, Pallonen, } \\
\text { Meshack [57] }\end{array}$ & $\begin{array}{l}2010 \text { in } \\
\text { USA }\end{array}$ & $\begin{array}{l}\text { To analyse impact } \\
\text { of immigration } \\
\text { status on tobacco } \\
\text { use }\end{array}$ & $\begin{array}{l}\text { Chinese } \\
\text { Americans } \\
\text { (country of birth, } \\
\text { country of } \\
\text { residence before } \\
\text { immigration) }\end{array}$ & $\begin{array}{l}\text { Chinese-American } \\
\text { households with } \\
\text { listed residential } \\
\text { telephone } \\
\text { numbers and list } \\
\text { of Chinese } \\
\text { surnames, random } \\
\text { household } \\
\text { selection by } \\
\text { stratified } \\
\text { probability } \\
\text { sampling method } \\
\text { with } \\
\text { geographically } \\
\text { proportional } \\
\text { allocation, } \\
\text { additional public } \\
\text { relations work }\end{array}$ & $\begin{array}{l}\text { Self- } \\
\text { administered } \\
\text { (mail) and } \\
\text { telephone- } \\
\text { administered } \\
\text { survey (trans- } \\
\text { lated instru- } \\
\text { ment, bilin- } \\
\text { gual } \\
\text { interviewers) }\end{array}$ & $\begin{array}{l}\text { Cross- } \\
\text { sectional }\end{array}$ & $\begin{array}{l}1,054 \text { (94\% } \\
\text { foreign- } \\
\text { born) }\end{array}$ & $\begin{array}{l}\text { DV: current smoker } \\
\text { vs. non-smoker IV: } \\
\text { age, income, edu- } \\
\text { cation, years living } \\
\text { in the USA }\end{array}$ & $\begin{array}{l}\text { Logistic } \\
\text { regression } \\
\text { Highest } \\
\text { statistical } \\
\text { analysis only for } \\
\text { males }\end{array}$ & $\begin{array}{l}\text { Failure to reach } \\
\text { two-thirds of all } \\
\text { potential respon- } \\
\text { dents, more than } \\
\text { one-third of poten- } \\
\text { tial respondents in } \\
\text { initial sampling } \\
\text { frame denied they } \\
\text { were Chinese, } \\
\text { small sample size } \\
\text { of female Chinese- } \\
\text { American smokers }\end{array}$ \\
\hline 3 & $\begin{array}{l}\text { Al-Omari, } \\
\text { Scheibmeir [58] }\end{array}$ & $\begin{array}{l}2009 \text { in } \\
\text { USA }\end{array}$ & $\begin{array}{l}\text { To describe } \\
\text { relationship } \\
\text { between tobacco } \\
\text { use and } \\
\text { psychological } \\
\text { acculturation }\end{array}$ & $\begin{array}{l}\text { Arab American } \\
\text { (country of birth) }\end{array}$ & $\begin{array}{l}\text { Convenience- } \\
\text { sampling method: } \\
2 \text { grocery stores } \\
\text { and one Islamic } \\
\text { center were used } \\
\text { to recruit } \\
\text { participants }\end{array}$ & $\begin{array}{l}\text { Self- } \\
\text { administered } \\
\text { survey } \\
\text { (instrument } \\
\text { only in } \\
\text { English, no } \\
\text { information } \\
\text { on presence } \\
\text { of bilingual } \\
\text { interviewers) }\end{array}$ & $\begin{array}{l}\text { Cross- } \\
\text { sectional }\end{array}$ & $\begin{array}{l}96(100 \% \\
\text { foreign- } \\
\text { born) }\end{array}$ & $\begin{array}{l}\text { Nicotine } \\
\text { dependence with } \\
\text { tobacco exposure } \\
\text { and acculturation } \\
\text { (acculturation also } \\
\text { by gender) }\end{array}$ & $\begin{array}{l}\text { Pearson } \\
\text { correlation } \\
\text { statistics }\end{array}$ & $\begin{array}{l}\text { Small number of } \\
\text { participants and } \\
\text { nonrandomised } \\
\text { sampling, large } \\
\text { overrepresentation } \\
\text { of men in sample, } \\
\text { instrument only } \\
\text { available in English } \\
\text { language }\end{array}$ \\
\hline 4 & Stoddard [59] & $\begin{array}{l}2009 \text { in } \\
\text { USA }\end{array}$ & $\begin{array}{l}\text { To examine impact } \\
\text { of social and }\end{array}$ & $\begin{array}{l}\text { Mexican American } \\
\text { (self-identification) }\end{array}$ & $\begin{array}{l}\text { Data source: } \\
\text { National Health }\end{array}$ & $\begin{array}{l}\text { Interviewer- } \\
\text { administered }\end{array}$ & $\begin{array}{l}\text { Cross- } \\
\text { sectional }\end{array}$ & & $\begin{array}{l}\text { DV: risk of regular } \\
\text { smoking initiation }\end{array}$ & $\begin{array}{l}\text { Discrete-time } \\
\text { hazard analysis }\end{array}$ & $\begin{array}{l}\text { Only limited } \\
\text { analysis of social }\end{array}$ \\
\hline
\end{tabular}


Table 4 Methodological quality assessment of the articles included in the review (Continued)

\begin{tabular}{|c|c|c|c|c|c|c|c|c|c|c|c|}
\hline & & & $\begin{array}{l}\text { structural factors } \\
\text { on risk of smoking } \\
\text { initiation among } \\
\text { immigrants before } \\
\text { and after } \\
\text { immigration }\end{array}$ & & $\begin{array}{l}\text { Interview Survey } \\
\text { (NHIS) (nationally } \\
\text { representative } \\
\text { survey in the USA } \\
\text { conducted } \\
\text { annually) }\end{array}$ & $\begin{array}{l}\text { survey } \\
\text { (translated } \\
\text { instrument, } \\
\text { bilingual } \\
\text { interviewers) }\end{array}$ & & $\begin{array}{l}6,935(58 \% \\
\text { foreign- } \\
\text { born) }\end{array}$ & $\begin{array}{l}\text { IV: age, education, } \\
\text { country of } \\
\text { smoking initiation }\end{array}$ & $\begin{array}{l}\text { Stratified by } \\
\text { gender }\end{array}$ & $\begin{array}{l}\text { and structural } \\
\text { factors, use of } \\
\text { retrospective data } \\
\text { on age at } \\
\text { immigration and } \\
\text { age of smoking } \\
\text { initiation (recall } \\
\text { bias due to cohort } \\
\text { design possible), } \\
\text { data on exact age } \\
\text { at immigration } \\
\text { were unavailable } \\
\text { and had to be } \\
\text { approximated or } \\
\text { imputed }\end{array}$ \\
\hline 5 & $\begin{array}{l}\text { Maxwell, Garcia, } \\
\text { Berman [60] }\end{array}$ & $\begin{array}{l}2007 \text { in } \\
\text { USA }\end{array}$ & $\begin{array}{l}\text { To examine } \\
\text { knowledge, beliefs } \\
\text { and attitudes } \\
\text { towards smoking } \\
\text { and to examine } \\
\text { relationship } \\
\text { between i.e. } \\
\text { duration of stay } \\
\text { and acculturation } \\
\text { with smoking }\end{array}$ & $\begin{array}{l}\text { Male Filipino } \\
\text { Americans } \\
\text { (probably self- } \\
\text { identification, not } \\
\text { further specified) }\end{array}$ & $\begin{array}{l}\text { Sampling by } \\
\text { approach of } \\
\text { community-based } \\
\text { organizations serv- } \\
\text { ing Filipino Ameri- } \\
\text { cans, Filipino } \\
\text { American associa- } \\
\text { tions, Christian } \\
\text { churches, } \\
\text { businesses }\end{array}$ & $\begin{array}{l}\text { Interviewer- } \\
\text { administered } \\
\text { survey } \\
\text { (translated } \\
\text { instrument, } \\
\text { bilingual } \\
\text { interviewers) }\end{array}$ & $\begin{array}{l}\text { Cross- }^{-} \\
\text {sectional }\end{array}$ & $\begin{array}{l}318(100 \% \\
\text { foreign- } \\
\text { born) }\end{array}$ & $\begin{array}{l}\text { DV: current smoker } \\
\text { vs. non-smoker IV: } \\
\text { age, duration of } \\
\text { residency in USA, } \\
\text { English usage with } \\
\text { friends, education, } \\
\text { income, employ- } \\
\text { ment, health insur- } \\
\text { ance, knowledge } \\
\text { score, smoking be- } \\
\text { liefs score, per- } \\
\text { ceived risk of lung } \\
\text { cancer, perceived } \\
\text { risk of smoking- } \\
\text { related diseases, } \\
\text { most friends } \\
\text { smoke }\end{array}$ & $\begin{array}{l}\text { Logistic } \\
\text { regression }\end{array}$ & $\begin{array}{l}\text { Community } \\
\text { sampling, sample } \\
\text { was restricted to } \\
\text { Filipino men aged } \\
40-75 \text { years, cross- } \\
\text { sectional design, } \\
\text { assessment of } \\
\text { some constructs } \\
\text { with only single } \\
\text { items to keep sur- } \\
\text { vey brief }\end{array}$ \\
\hline 6 & $\begin{array}{l}\text { An, Cochran, } \\
\text { Mays, McCarthy } \\
\text { [61] }\end{array}$ & $\begin{array}{l}2008 \text { in } \\
\text { USA }\end{array}$ & $\begin{array}{l}\text { To estimate effects } \\
\text { of multiple } \\
\text { acculturation } \\
\text { indicators on } \\
\text { current smoking, } \\
\text { to compare } \\
\text { gender- and ethnic } \\
\text { subgroup-specific } \\
\text { current smoking } \\
\text { prevalence, to } \\
\text { examine effects of } \\
\text { other potential } \\
\text { predictors of smok- } \\
\text { ing behavior for } \\
\text { men and women }\end{array}$ & $\begin{array}{l}\text { Chinese, Filipino, } \\
\text { South Asian, } \\
\text { Japanese, Korean, } \\
\text { and Vietnamese } \\
\text { Americans } \\
\text { (probably self- } \\
\text { identification, not } \\
\text { further specified) }\end{array}$ & $\begin{array}{l}\text { Data source: } 2001 \\
\text { and } 2003 \text { California } \\
\text { Health Interview } \\
\text { Survey (CHIS) } \\
\text { (household survey } \\
\text { conducted by } \\
\text { random-digit dial- } \\
\text { ing with oversam- } \\
\text { pling of areas with } \\
\text { high concentra- } \\
\text { tions of specific } \\
\text { ethnic groups) }\end{array}$ & $\begin{array}{l}\text { Telephone- } \\
\text { administered } \\
\text { survey } \\
\text { (translated } \\
\text { instrument, } \\
\text { bilingual } \\
\text { interviewers) }\end{array}$ & $\begin{array}{l}\text { Cross- } \\
\text { sectional }\end{array}$ & $\begin{array}{l}8192 \\
\text { (foreign- } \\
\text { born: } \\
\text { Chinese } \\
\text { 91\%, Filipino } \\
90 \%, \text { South } \\
\text { Asian 96\%, } \\
\text { Korea 94\%, } \\
\text { Vietnam } \\
\text { 98\%) }\end{array}$ & $\begin{array}{l}\text { DV: current smoker } \\
\text { vs. non-smoker IV: } \\
\text { education, marital } \\
\text { status, alcohol con- } \\
\text { sumption, poverty } \\
\text { level, health care, } \\
\text { insurance, lan- } \\
\text { guage, length of } \\
\text { stay, ethnicity }\end{array}$ & $\begin{array}{l}\text { Logistic } \\
\text { regression } \\
\text { Stratified by } \\
\text { gender, not } \\
\text { stratified by } \\
\text { nativity }\end{array}$ & $\begin{array}{l}\text { South Asian } \\
\text { American women } \\
\text { use smokeless } \\
\text { tobacco primarily } \\
\text { (risk of } \\
\text { underestimation of } \\
\text { total tobacco use), } \\
\text { cross-sectional de- } \\
\text { sign, use of exist- } \\
\text { ing data } \\
\text { constrained investi- } \\
\text { gators' measures of } \\
\text { acculturation (avail- } \\
\text { able measures did } \\
\text { not capture multi- } \\
\text { dimensional nature } \\
\text { of acculturation) }\end{array}$ \\
\hline
\end{tabular}


Table 4 Methodological quality assessment of the articles included in the review (Continued)

\begin{tabular}{|c|c|c|c|c|c|c|c|c|c|c|c|}
\hline 7 & $\begin{array}{l}\text { Maxwell, } \\
\text { Bernaards, } \\
\text { McCarthy [62] }\end{array}$ & $\begin{array}{l}2005 \text { in } \\
\text { USA }\end{array}$ & $\begin{array}{l}\text { To report smoking } \\
\text { rates among } \\
\text { different ethnic } \\
\text { groups and to } \\
\text { compare correlates } \\
\text { of smoking among } \\
\text { Chinese \& Filipino } \\
\text { Americans and } \\
\text { Hispanic } \\
\text { Americans }\end{array}$ & $\begin{array}{l}\text { Chinese \& Filipino } \\
\text { Americans, } \\
\text { Hispanic } \\
\text { Americans, } \\
\text { additionally } \\
\text { African/Black } \\
\text { Americans, } \\
\text { American Indian/ } \\
\text { Alaska Natives, } \\
\text { Pacific Islanders } \\
\text { (probably self- } \\
\text { identification, not } \\
\text { further specified) }\end{array}$ & $\begin{array}{l}\text { Data source: } 2001 \\
\text { California Health } \\
\text { Interview Survey } \\
\text { (CHIS) (household } \\
\text { survey conducted } \\
\text { by random-digit } \\
\text { dialing with over- } \\
\text { sampling of areas } \\
\text { with high concen- } \\
\text { trations of specific } \\
\text { ethnic groups) }\end{array}$ & $\begin{array}{l}\text { Telephone- } \\
\text { administered } \\
\text { survey } \\
\text { (translated } \\
\text { instrument, } \\
\text { bilingual } \\
\text { interviewers) }\end{array}$ & $\begin{array}{l}\text { Cross- } \\
\text { sectional }\end{array}$ & $\begin{array}{l}13,414 \\
\text { (foreign- } \\
\text { born: } \\
\text { Hispanics } \\
65 \% \text {, Asians } \\
77 \% \text { ) }\end{array}$ & $\begin{array}{l}\text { DV: current smoker } \\
\text { vs. non-smoker IV: } \\
\text { age, marital status, } \\
\text { education, employ- } \\
\text { ment, income, } \\
\text { country of birth, } \\
\text { years in the USA, } \\
\text { level of spoken } \\
\text { English }\end{array}$ & $\begin{array}{l}\text { Logistic } \\
\text { regression } \\
\text { Stratified by } \\
\text { nativity and } \\
\text { gender }\end{array}$ & $\begin{array}{l}\text { All data are based } \\
\text { on self-report, } \\
\text { cross-sectional de- } \\
\text { sign, only house- } \\
\text { holds were } \\
\text { reached that had a } \\
\text { telephone, only } \\
\text { few items were } \\
\text { available to assess } \\
\text { acculturation, no } \\
\text { questions about } \\
\text { other tobacco } \\
\text { products }\end{array}$ \\
\hline 8 & $\begin{array}{l}\text { Rahman, Luong, } \\
\text { Divan, Jesser, } \\
\text { Golz, Thirumalai, } \\
\text { Reedy, Olivas } \\
\text { [63] }\end{array}$ & $\begin{array}{l}2005 \text { in } \\
\text { USA }\end{array}$ & $\begin{array}{l}\text { To examine } \\
\text { smoking } \\
\text { prevalence as well } \\
\text { as factorsthat may } \\
\text { be associated with } \\
\text { smoking }\end{array}$ & $\begin{array}{l}\text { Male Vietnamese } \\
\text { Americans } \\
\text { (probably self- } \\
\text { identification, not } \\
\text { further specified) }\end{array}$ & $\begin{array}{l}\text { Sample drawn } \\
\text { from Vietnamese } \\
\text { surnames listed in } \\
\text { telephone } \\
\text { directory, } \\
\text { residential } \\
\text { telephone } \\
\text { numbers were } \\
\text { eligible for } \\
\text { sampling, random- } \\
\text { digit-dialing sam- } \\
\text { pling procedure }\end{array}$ & $\begin{array}{l}\text { Telephone- } \\
\text { administered } \\
\text { survey } \\
\text { (translated } \\
\text { instrument, } \\
\text { bilingual } \\
\text { interviewers) }\end{array}$ & $\begin{array}{l}\text { Cross- } \\
\text { sectional }\end{array}$ & $\begin{array}{l}660(100 \% \\
\text { foreign- } \\
\text { born) }\end{array}$ & $\begin{array}{l}\text { DV: current smoker } \\
\text { vs. non-smoker IV: } \\
\text { age, income, edu- } \\
\text { cation, marital sta- } \\
\text { tus, English } \\
\text { language profi- } \\
\text { ciency, language } \\
\text { used at home, lan- } \\
\text { guage used with } \\
\text { friends, length of } \\
\text { stay in USA, blood } \\
\text { cholesterol check, } \\
\text { routine physical } \\
\text { check up, binge } \\
\text { drinker, multiple } \\
\text { sex partners }\end{array}$ & $\begin{array}{l}\text { Logistic } \\
\text { regression }\end{array}$ & $\begin{array}{l}\text { Random-digit- } \\
\text { dialing } \\
\text { methodology } \\
\text { excluded potential } \\
\text { respondents } \\
\text { without } \\
\text { telephones, self- } \\
\text { report of smoking, } \\
\text { findings may not } \\
\text { be representative } \\
\text { of the behavioural } \\
\text { risk factors for Viet- } \\
\text { namese who reside } \\
\text { in other states than } \\
\text { California }\end{array}$ \\
\hline 9 & $\begin{array}{l}\text { Wilkinson, Spitz, } \\
\text { Strom, } \\
\text { Prokhorov, } \\
\text { Barcenas, Cao, } \\
\text { Saunders, } \\
\text { Bondy [64] }\end{array}$ & $\begin{array}{l}2005 \text { in } \\
\text { USA }\end{array}$ & $\begin{array}{l}\text { To analyze } \\
\text { smoking by age, } \\
\text { education, } \\
\text { acculturation, and } \\
\text { country of birth, to } \\
\text { investigate } \\
\text { differences in } \\
\text { smoking behaviour } \\
\text { among US- and } \\
\text { foreign-born } \\
\text { smokers and to } \\
\text { examine role of ex- } \\
\text { posure to US cul- } \\
\text { ture in smoking }\end{array}$ & $\begin{array}{l}\text { Mexican } \\
\text { Americans } \\
\text { (probably self- } \\
\text { identification, not } \\
\text { further specified) }\end{array}$ & $\begin{array}{l}\text { Data was used } \\
\text { from ongoing } \\
\text { cohort of Mexican } \\
\text { American } \\
\text { households } \\
\text { (participants were } \\
\text { recruited through } \\
\text { random-digit dial- } \\
\text { ing, "block walk- } \\
\text { ing", "intercept" } \\
\text { (i.e., recruiting indi- } \\
\text { viduals from e.g. } \\
\text { community centers } \\
\text { or local health } \\
\text { clinics), and net- } \\
\text { working via already } \\
\text { enrolled } \\
\text { participants) }\end{array}$ & $\begin{array}{l}\text { Self- } \\
\text { administered } \\
\text { survey } \\
\text { (translated } \\
\text { instruments, } \\
\text { bilingual } \\
\text { interviewers } \\
\text { present) }\end{array}$ & $\begin{array}{l}\text { Cross- }^{-} \\
\text {sectional }\end{array}$ & $\begin{array}{l}5,030(70 \% \\
\text { foreign- } \\
\text { born) }\end{array}$ & $\begin{array}{l}\text { DV: current smoker } \\
\text { vs. non-smokerlV: } \\
\text { age, gender, edu- } \\
\text { cation, accultur- } \\
\text { ation, age at } \\
\text { migration, context- } \\
\text { ual level (home } \\
\text { ownership, Spanish } \\
\text { speaking, more } \\
\text { than high school } \\
\text { education, US- } \\
\text { born, median age), } \\
\text { age at migration }\end{array}$ & $\begin{array}{l}\text { Logistic } \\
\text { regression } \\
\text { Stratified by } \\
\text { country of birth } \\
\text { (1 model for US- } \\
\text { born persons, } 2 \\
\text { models for } \\
\text { Mexican-born } \\
\text { persons) }\end{array}$ & $\begin{array}{l}\text { Cross-sectional } \\
\text { design, unable to } \\
\text { assess influence of } \\
\text { family contexts on } \\
\text { smoking, smoking } \\
\text { was self-reported, } \\
\text { other key variables } \\
\text { (age at migration } \\
\text { and country where } \\
\text { smoking was initi- } \\
\text { ated) were calcu- } \\
\text { lated on the basis } \\
\text { of self-reports (not } \\
\text { directly assessed) }\end{array}$ \\
\hline 10 & $\begin{array}{l}\text { Hofstetter, } \\
\text { Hovell, Lee, }\end{array}$ & $\begin{array}{l}2004 \text { in } \\
\text { USA }\end{array}$ & $\begin{array}{l}\text { To examine } \\
\text { tobacco use and } \\
\text { its determinants }\end{array}$ & $\begin{array}{l}\text { Korean Americans } \\
\text { (probably self- }\end{array}$ & $\begin{array}{l}\text { Sampling frame } \\
\text { based on } \\
\text { residential }\end{array}$ & $\begin{array}{l}\text { Telephone- } \\
\text { administered } \\
\text { survey }\end{array}$ & $\begin{array}{l}\text { Cross- }^{-} \\
\text {sectional }\end{array}$ & $\begin{array}{l}2,830(94 \% \\
\text { foreign- } \\
\text { born) }\end{array}$ & $\begin{array}{l}\text { DV: smoking; } \\
\text { smoking uptake; } \\
\text { age at first }\end{array}$ & $\begin{array}{l}\text { Ordinary least } \\
\text { squares analysis } \\
\text { and logistic }\end{array}$ & $\begin{array}{l}\text { Design as } \\
\text { telephone survey } \\
\text { where no }\end{array}$ \\
\hline
\end{tabular}


Table 4 Methodological quality assessment of the articles included in the review (Continued)

\begin{tabular}{|c|c|c|c|c|c|c|c|c|c|c|c|}
\hline & $\begin{array}{l}\text { Zakarian, Park, } \\
\text { Paik, Irvin [65] }\end{array}$ & & $\begin{array}{l}\text { with special } \\
\text { emphasis on } \\
\text { acculturation }\end{array}$ & $\begin{array}{l}\text { identification, not } \\
\text { further specified) }\end{array}$ & $\begin{array}{l}\text { telephones listed } \\
\text { to Korean } \\
\text { surnames, list was } \\
\text { sorted into } \\
\text { random order for } \\
\text { interviewing }\end{array}$ & $\begin{array}{l}\text { (translated } \\
\text { instrument, } \\
\text { bilingual } \\
\text { interviewers) }\end{array}$ & & & $\begin{array}{l}\text { cigarette; smoke } \\
\text { cigarette if offered } \\
\text { by a friend (yes vs. } \\
\text { no) IV: age, } \\
\text { education, } \\
\text { employment } \\
\text { status, } \\
\text { acculturation, } \\
\text { social support, } \\
\text { models who } \\
\text { smoke }\end{array}$ & $\begin{array}{l}\text { regression } \\
\text { Interaction } \\
\text { terms between } \\
\text { gender and } \\
\text { each IV }\end{array}$ & $\begin{array}{l}\text { information on } \\
\text { persons without } \\
\text { residential } \\
\text { telephones was } \\
\text { available, cross- } \\
\text { sectional design }\end{array}$ \\
\hline 11 & $\begin{array}{l}\text { Shelley, Fahs, } \\
\text { Scheinmann, } \\
\text { Swain, Qu, } \\
\text { Burton [66] }\end{array}$ & $\begin{array}{l}2004 \text { in } \\
\text { USA }\end{array}$ & $\begin{array}{l}\text { To describe } \\
\text { tobacco use } \\
\text { knowledge, } \\
\text { attitudes and } \\
\text { behaviours and to } \\
\text { examine } \\
\text { association } \\
\text { between patterns } \\
\text { of tobacco use } \\
\text { and acculturation }\end{array}$ & $\begin{array}{l}\text { Chinese } \\
\text { Americans (self- } \\
\text { identification) }\end{array}$ & $\begin{array}{l}\text { List of Chinese } \\
\text { surnames, } \\
\text { application of } \\
\text { stratified } \\
\text { systematic } \\
\text { sampling } \\
\text { procedure (2 } \\
\text { stages: first, sample } \\
\text { cohort of Chinese } \\
\text { American } \\
\text { households was } \\
\text { identified and data } \\
\text { gathered of all } \\
\text { adults within } \\
\text { households; } \\
\text { second, } 3 \text { sample } \\
\text { groups of adults } \\
\text { aged 18-64 years } \\
\text { were selected for } \\
\text { extended inter- } \\
\text { view: (1) current } \\
\text { smokers, (2) non- } \\
\text { smoking men, and } \\
\text { (3) women }\end{array}$ & $\begin{array}{l}\text { Interviewer- } \\
\text { administered } \\
\text { survey } \\
\text { (translated } \\
\text { instrument, } \\
\text { bilingual } \\
\text { interviewers) }\end{array}$ & $\begin{array}{l}\text { Cross- } \\
\text { sectional }\end{array}$ & $\begin{array}{l}712(97 \% \\
\text { foreign- } \\
\text { born) }\end{array}$ & $\begin{array}{l}\text { DV: current smoker } \\
\text { vs. former smoker, } \\
\text { never smoker vs. } \\
\text { ever smoker IV: } \\
\text { age, education, } \\
\text { employment, } \\
\text { marital status, } \\
\text { insurance, health } \\
\text { care use, } \\
\text { knowledge of } \\
\text { tobacco risks, } \\
\text { English language } \\
\text { used at home, } \\
\text { reading of English } \\
\text { newspapers }\end{array}$ & $\begin{array}{l}\text { Logistic } \\
\text { regression } \\
\text { Highest } \\
\text { statistical } \\
\text { analysis only for } \\
\text { males }\end{array}$ & $\begin{array}{l}\text { Preliminary results } \\
\text { to be confirmed by } \\
\text { analysis of full } \\
\text { sample, sampling } \\
\text { frame was based } \\
\text { on subjects living } \\
\text { in households with } \\
\text { listed telephones, } \\
\text { self-reports were } \\
\text { not validated }\end{array}$ \\
\hline 12 & $\begin{array}{l}\text { Fu, Ma, Tu, Siu, } \\
\text { Metlay [67] }\end{array}$ & $\begin{array}{l}2003 \text { in } \\
\text { USA }\end{array}$ & $\begin{array}{l}\text { To assess whether } \\
\text { greater level of } \\
\text { acculturation was } \\
\text { associated with } \\
\text { decreased current } \\
\text { cigarette smoking }\end{array}$ & $\begin{array}{l}\text { Chinese } \\
\text { Americans (self- } \\
\text { identification) }\end{array}$ & $\begin{array}{l}\text { Recruitment in } \\
\text { medical practices } \\
\text { with fluent } \\
\text { Chinese-speaking } \\
\text { providers }\end{array}$ & $\begin{array}{l}\text { Self- } \\
\text { administered } \\
\text { survey } \\
\text { (translated } \\
\text { instrument, } \\
\text { bilingual } \\
\text { interviewers } \\
\text { present) }\end{array}$ & $\begin{array}{l}\text { Cross- } \\
\text { sectional }\end{array}$ & $\begin{array}{l}541(98 \% \\
\text { foreign- } \\
\text { born) }\end{array}$ & $\begin{array}{l}\text { DV: current smoker } \\
\text { vs. non-smoker IV: } \\
\text { acculturation Ad- } \\
\text { justed for age, } \\
\text { study site, educa- } \\
\text { tion level, income }\end{array}$ & $\begin{array}{l}\text { Logistic } \\
\text { regression } \\
\text { Highest } \\
\text { statistical } \\
\text { analysis only for } \\
\text { males }\end{array}$ & $\begin{array}{l}\text { Language } \\
\text { proficiency only } \\
\text { one dimension of } \\
\text { acculturation, study } \\
\text { subjects were a } \\
\text { convenient sample } \\
\text { of patients at } \\
\text { medical or dental } \\
\text { practices, } \\
\text { differences } \\
\text { between } \\
\text { participating and } \\
\text { non-participating } \\
\text { clinics may limit } \\
\text { validity of results, }\end{array}$ \\
\hline
\end{tabular}


14 Ma, Shive, Tan, 2002 in Toubbeh [69] USA
$15 \mathrm{Yu}$, Chen, Kim, 2002 in Abdulrahim [70] USA

\section{To examine prevalence of smoking and the
correlated factors of smoking}

To determine tobacco use rates and to determine demographic variables that are potential

predictors of tobacco use
To describe and examine factors significantly associated with smoking

\author{
Male Korean \\ immigrants \\ (country of birth) \\ Community-based Sef- \\ sampling in six \\ and two Korean \\ grocery stores
}

\section{Self-} adminis (translated

instrument, in exceptional

cases

administered

survey with

bilingual

interviewers)

Chinese, Korean, Vietnamese and Cambodian Americans (selfidentification) and division of Asian Ame community organisations into
clusters, stratification of selected organization InterviewerCross- $\quad 1,174(94 \%$ sectional foreign(bilingual

interviewers no

clusters according

to 4 ethnicity

groups (Chinese,

Korean,

Vietnamese,

(ambodian), use of proportional

allocation

procedure in

which sample sizes

were assigned

proportionally to

subgroups

\section{Chinese}

Americans (selfidentification)

List of Chinatown residents was generated by merging compiled

Interview information instrument) surnames,

self-reported smok

ing behaviour, very small number of

female cigarette

smokers

Exclusion of those who do not go to church or

groceries

underreporting of smoking during survey in church, length of stay only one dimension of acculturation

history of

hypertension, regular check-up, alcohol use $\begin{array}{lll}\text { DV: current smoker } & \text { Logistic } & \text { Cross-sectional } \\ \text { vs. non-smoker IV: } & \text { regression Not } & \text { design, self-report }\end{array}$ gender, age, edu- stratified by procedure, modification, marital nativity cations of the simstatus

ple random

sampling design had to be applied to facilitate greater access to the communities

No limitations reported Very small telephone bilingual directories and interviewers) Chinese

newspaper

subscribers, twostage probability

$\begin{array}{lll}\text { education, usual } & \text { Highest } & \text { number of female } \\ \text { source of health } & \text { statistical } & \text { smokers, cross- } \\ \text { care, knowledge of } & \text { analysis only for } & \text { sectional design, }\end{array}$

$\begin{array}{lll}\text { education, usual } & \text { Highest } & \text { number of femal } \\ \text { source of health } & \text { statistical } & \text { smokers, cross- } \\ \text { care, knowledge of } & \text { analysis only for } & \text { sectional design, }\end{array}$ $\begin{array}{lll}\begin{array}{ll}\text { care, knowledge of } \\ \text { cancer warning }\end{array} & \text { malysis only for } & \begin{array}{l}\text { sectional design, } \\ \text { selection bias due }\end{array}\end{array}$ signs

cedure, sample

was restricted to

Chinese men aged

40-69 years 


\begin{tabular}{|c|c|c|c|c|c|c|c|c|c|c|c|}
\hline & & & & & $\begin{array}{l}\text { sampling method } \\
\text { to randomly select } \\
\text { Chinese } \\
\text { households }\end{array}$ & & & & & & \\
\hline 16 & $\begin{array}{l}\text { Kim, Yu, Chen, } \\
\text { Kim, Brintnall, } \\
\text { Vance [71] }\end{array}$ & $\begin{array}{l}2000 \text { in } \\
\text { USA }\end{array}$ & $\begin{array}{l}\text { To examine } \\
\text { smoking } \\
\text { behaviour, } \\
\text { knowledge and } \\
\text { beliefs and to } \\
\text { better understand } \\
\text { tobacco-related } \\
\text { factors }\end{array}$ & $\begin{array}{l}\text { Korean Americans } \\
\text { (probably self- } \\
\text { identification, not } \\
\text { further specified) }\end{array}$ & $\begin{array}{l}\text { Compilation of list } \\
\text { with Korean } \\
\text { household names, } \\
\text { Korean newspaper } \\
\text { subscribers, } \\
\text { participants in } \\
\text { Korean community } \\
\text { centre, two-stage } \\
\text { probability sam- } \\
\text { pling method to } \\
\text { randomly select } \\
\text { Korean households }\end{array}$ & $\begin{array}{l}\text { Interviewer- } \\
\text { administered } \\
\text { survey } \\
\text { (translated } \\
\text { instrument, } \\
\text { bilingual } \\
\text { interviewers) }\end{array}$ & $\begin{array}{l}\text { Cross- } \\
\text { sectional }\end{array}$ & $\begin{array}{l}263(100 \% \\
\text { foreign- } \\
\text { born) }\end{array}$ & $\begin{array}{l}\text { DV: current smoker } \\
\text { vs. non-smoker IV: } \\
\text { age, education, re- } \\
\text { ligion, English pro- } \\
\text { ficiency, length of } \\
\text { stay in USA }\end{array}$ & $\begin{array}{l}\text { Logistic } \\
\text { regression } \\
\text { Highest } \\
\text { statistical } \\
\text { analysis only for } \\
\text { males }\end{array}$ & $\begin{array}{l}\text { No limitations } \\
\text { reported Very small } \\
\text { number of female } \\
\text { smokers, cross- } \\
\text { sectional design, } \\
\text { selection bias due } \\
\text { to sampling pro- } \\
\text { cedure, sample } \\
\text { was restricted to } \\
\text { Korean men aged } \\
40-69 \text { years }\end{array}$ \\
\hline 17 & $\begin{array}{l}\text { Shankar, } \\
\text { Gutierrez- } \\
\text { Mohamed, } \\
\text { Alberg [72] }\end{array}$ & $\begin{array}{l}2000 \text { in } \\
\text { USA }\end{array}$ & $\begin{array}{l}\text { To describe } \\
\text { smoking } \\
\text { prevalence and to } \\
\text { evaluate attitudes } \\
\text { and beliefs } \\
\text { towards smoking }\end{array}$ & $\begin{array}{l}\text { El Salvadoran } \\
\text { immigrants } \\
\text { (country of birth) }\end{array}$ & $\begin{array}{l}\text { Survey of } \\
\text { Salvadoreans living } \\
\text { in the Washington } \\
\text { DC metropolitan } \\
\text { area (not further } \\
\text { specified, with } \\
\text { reference to } \\
\text { publication on } \\
\text { sampling details) }\end{array}$ & $\begin{array}{l}\text { Interviewer- } \\
\text { administered } \\
\text { survey } \\
\text { (bilingual } \\
\text { interviewers, } \\
\text { no } \\
\text { information } \\
\text { on translated } \\
\text { instrument) }\end{array}$ & $\begin{array}{l}\text { Cross- } \\
\text { sectional }\end{array}$ & $\begin{array}{l}1,458(100 \% \\
\text { foreign- } \\
\text { born) }\end{array}$ & $\begin{array}{l}\text { DV: prevalence } \\
\text { difference (current } \\
\text { vs. never; former } \\
\text { vs. never) IV: age, } \\
\text { gender, marital } \\
\text { status, household } \\
\text { size, employment } \\
\text { status, income, } \\
\text { years of schooling, } \\
\text { age at migration }\end{array}$ & $\begin{array}{l}\text { Linear } \\
\text { regression }\end{array}$ & $\begin{array}{l}\text { No limitations } \\
\text { reported Very small } \\
\text { number of female } \\
\text { smokers, recently } \\
\text { immigrated group } \\
\text { and heavily } \\
\text { weighted towards } \\
\text { young persons, no } \\
\text { association } \\
\text { between smoking } \\
\text { and } \\
\text { socioeconomic } \\
\text { status were found } \\
\text { at all }\end{array}$ \\
\hline 18 & $\begin{array}{l}\text { King, Polednak, } \\
\text { Bendel, Hovey } \\
\text { [73] }\end{array}$ & $\begin{array}{l}1999 \text { in } \\
\text { USA }\end{array}$ & $\begin{array}{l}\text { To examine } \\
\text { differences in } \\
\text { smoking between } \\
\text { foreign- and } \\
\text { native-born per- } \\
\text { sons and to exam- } \\
\text { ine impact of } \\
\text { demographic and } \\
\text { socioeconomic sta- } \\
\text { tus on smoking }\end{array}$ & $\begin{array}{l}\text { African/Black } \\
\text { Americans } \\
\text { (country of birth, } \\
\text { self-identification) }\end{array}$ & $\begin{array}{l}\text { Data source: } \\
\text { National Health } \\
\text { Interview Survey } \\
\text { (NHIS) (nationally } \\
\text { representative } \\
\text { survey in the USA } \\
\text { conducted } \\
\text { annually), } \\
\text { additional merging } \\
\text { of Cancer Control } \\
\text { Supplement (CCS) } \\
\text { and Cancer } \\
\text { Epidemiology } \\
\text { Supplement (CES) } \\
\text { to increase } \\
\text { representation of } \\
\text { African/Black } \\
\text { Americans }\end{array}$ & $\begin{array}{l}\text { Interviewer- } \\
\text { administered } \\
\text { survey (no } \\
\text { information } \\
\text { on translated } \\
\text { instrument or } \\
\text { bilingual } \\
\text { interviewers) }\end{array}$ & $\begin{array}{l}\text { Cross- } \\
\text { sectional }\end{array}$ & $\begin{array}{l}16,738(7 \% \\
\text { foreign- } \\
\text { born) }\end{array}$ & $\begin{array}{l}\text { DV: current smoker } \\
\text { vs. non-smoker IV: } \\
\text { age, gender, edu- } \\
\text { cation, income, } \\
\text { length of stay in } \\
\text { USA, nativity (na- } \\
\text { tive- vs. foreign- } \\
\text { born), employ- } \\
\text { ment, marital sta- } \\
\text { tus, region }\end{array}$ & $\begin{array}{l}\text { Logistic } \\
\text { regression }\end{array}$ & $\begin{array}{l}\text { Possibility of } \\
\text { underestimating } \\
\text { smoking } \\
\text { prevalence due to } \\
\text { undocumented } \\
\text { residents and non- } \\
\text { respondent bias, } \\
\text { sampling error due } \\
\text { to undercoverage, } \\
\text { NHIS data is cross- } \\
\text { sectional }\end{array}$ \\
\hline
\end{tabular}


Table 4 Methodological quality assessment of the articles included in the review (Continued)

\begin{tabular}{|c|c|c|c|c|c|c|c|c|c|c|c|}
\hline 19 & $\begin{array}{l}\text { Wiecha, Lee, } \\
\text { Hodgkins [74] }\end{array}$ & $\begin{array}{l}1998 \text { in } \\
\text { USA }\end{array}$ & $\begin{array}{l}\text { To measure } \\
\text { prevalence and } \\
\text { patterns of } \\
\text { tobacco use and } \\
\text { to identify } \\
\text { smoking risk } \\
\text { factors and } \\
\text { readiness to quit } \\
\text { smoking }\end{array}$ & $\begin{array}{l}\text { Male Vietnamese } \\
\text { American } \\
\text { (probably self- } \\
\text { identification, not } \\
\text { further specified) }\end{array}$ & $\begin{array}{l}\text { Vietnamese names } \\
\text { were used to } \\
\text { construct a search } \\
\text { list, phone } \\
\text { numbers of } \\
\text { persons with one } \\
\text { of these names } \\
\text { were obtained by } \\
\text { manual abstraction } \\
\text { of directories } \\
\text { representing } \\
\text { communities with } \\
\text { the largest } \\
\text { Vietnamese } \\
\text { populations }\end{array}$ & $\begin{array}{l}\text { Telephone- } \\
\text { administered } \\
\text { survey } \\
\text { (bilingual } \\
\text { interviewers, } \\
\text { no } \\
\text { information } \\
\text { on translated } \\
\text { instruments) }\end{array}$ & $\begin{array}{l}\text { Cross- } \\
\text { sectional }\end{array}$ & $\begin{array}{l}774(100 \% \\
\text { foreign- } \\
\text { born) }\end{array}$ & $\begin{array}{l}\text { DV: current smoker } \\
\text { vs. non-smoker IV: } \\
\text { age, smoking par- } \\
\text { ents, education, ex- } \\
\text { ercise, depression, } \\
\text { health insurance, } \\
\text { part of Vietnam } \\
\text { raised in }\end{array}$ & $\begin{array}{l}\text { Logistic } \\
\text { regression }\end{array}$ & $\begin{array}{l}\text { Restriction to } \\
\text { males only, } \\
\text { sampling frame } \\
\text { was based on } \\
\text { subjects living in } \\
\text { households with } \\
\text { listed telephones, } \\
\text { depression } \\
\text { measures used are } \\
\text { likely to have been } \\
\text { relatively imprecise }\end{array}$ \\
\hline 20 & $\begin{array}{l}\text { Hyman, Fenta, } \\
\text { Noh [75] }\end{array}$ & $\begin{array}{l}2008 \text { in } \\
\text { Canada }\end{array}$ & $\begin{array}{l}\text { To present data on } \\
\text { risk and protective } \\
\text { factors associated } \\
\text { with smoking }\end{array}$ & $\begin{array}{l}\text { Ethiopian } \\
\text { immigrants } \\
\text { (country of birth) }\end{array}$ & $\begin{array}{l}\text { Snowball } \\
\text { technique } \\
\text { (membership lists } \\
\text { of Ethiopian } \\
\text { organizations) and } \\
\text { list of Ethiopian } \\
\text { names was } \\
\text { compiled using } \\
\text { city telephone } \\
\text { directory as } \\
\text { sampling frame, } \\
\text { household } \\
\text { selection using } \\
\text { simple random } \\
\text { sampling method, } \\
\text { additional public } \\
\text { relations work }\end{array}$ & $\begin{array}{l}\text { Interviewer- } \\
\text { administered } \\
\text { survey } \\
\text { (translated } \\
\text { instrument, } \\
\text { bilingual } \\
\text { interviewers) }\end{array}$ & $\begin{array}{l}\text { Cross- } \\
\text { sectional }\end{array}$ & $\begin{array}{l}342(100 \% \\
\text { foreign- } \\
\text { born) }\end{array}$ & $\begin{array}{l}\text { DV: current smoker } \\
\text { vs. non-smoker IV: } \\
\text { age, marital status, } \\
\text { importance of reli- } \\
\text { gion, education, } \\
\text { employment sta- } \\
\text { tus, length of stay } \\
\text { in Canada, expos- } \\
\text { ure to pre- } \\
\text { migration trauma, } \\
\text { refugee camp in- } \\
\text { ternment, number } \\
\text { of post-migration } \\
\text { life events, satisfac- } \\
\text { tion with social } \\
\text { support }\end{array}$ & $\begin{array}{l}\text { Logistic } \\
\text { regression } \\
\text { Results } \\
\text { presented from } \\
\text { bivariate } \\
\text { regression } \\
\text { (multivariate } \\
\text { analysis carried } \\
\text { out only for } \\
\text { males - results } \\
\text { not presented) } \\
\text { Bivariate analysis } \\
\text { stratified by } \\
\text { gender }\end{array}$ & $\begin{array}{l}\text { Exclusion of } \\
\text { potential } \\
\text { candidates if they } \\
\text { had no telephone, } \\
\text { stable address or } \\
\text { membership status } \\
\text { in Ethiopian } \\
\text { organisations, small } \\
\text { number of female } \\
\text { smokers prevented } \\
\text { further statistical } \\
\text { analyses }\end{array}$ \\
\hline 21 & $\begin{array}{l}\text { Kabir, Clarke, } \\
\text { Keogan, Currie, } \\
\text { Zatonski, Clancy } \\
{[76]}\end{array}$ & $\begin{array}{l}2008 \text { in } \\
\text { Ireland }\end{array}$ & $\begin{array}{l}\text { To identify } \\
\text { significant } \\
\text { predictors of } \\
\text { smoking }\end{array}$ & $\begin{array}{l}\text { Polish immigrants } \\
\text { (country of birth) }\end{array}$ & $\begin{array}{l}\text { Advertisement in } \\
\text { Polish lifestyle } \\
\text { magazine, } 10 \\
\text { Polish interviewers } \\
\text { were posted at } \\
\text { busy intersection } \\
\text { of the Dublin city } \\
\text { area (with } \\
\text { numerous Polish } \\
\text { shops) }\end{array}$ & $\begin{array}{l}\text { Interviewer- } \\
\text { administered } \\
\text { survey } \\
\text { (translated } \\
\text { instrument, } \\
\text { bilingual } \\
\text { interviewer) }\end{array}$ & $\begin{array}{l}\text { Cross- } \\
\text { sectional }\end{array}$ & $\begin{array}{l}1,545(100 \% \\
\text { foreign- } \\
\text { born) }\end{array}$ & $\begin{array}{l}\text { DV: current smoker } \\
\text { vs. non-smoker IV: } \\
\text { education, employ- } \\
\text { ment, duration of } \\
\text { stay Adjusted ana- } \\
\text { lysis (variables not } \\
\text { stated) }\end{array}$ & $\begin{array}{l}\text { Logistic } \\
\text { regression }\end{array}$ & $\begin{array}{l}\text { Very constrained } \\
\text { generalisability of } \\
\text { study findings } \\
\text { (high risk of } \\
\text { selection bias due } \\
\text { to sampling } \\
\text { procedure) }\end{array}$ \\
\hline 22 & $\begin{array}{l}\text { Reiss, Spallek, } \\
\text { Razum [77] }\end{array}$ & $\begin{array}{l}2010 \text { in } \\
\text { Germany }\end{array}$ & $\begin{array}{l}\text { To analyse } \\
\text { whether smoking } \\
\text { differs between } \\
\text { groups with } \\
\text { increasing duration } \\
\text { of stay }\end{array}$ & $\begin{array}{l}\text { Ethnic German } \\
\text { immigrants from } \\
\text { Former Soviet } \\
\text { Union countries } \\
\text { (birth in } \\
\text { Germany, } \\
\text { citizenship, } \\
\text { naturalization) }\end{array}$ & $\begin{array}{l}\text { Data source: } \\
\text { German } \\
\text { microcensus } \\
\text { (annual } \\
\text { countrywide } \\
\text { census including } \\
1 \% \text { of all German } \\
\text { households, }\end{array}$ & $\begin{array}{l}\text { Interviewer- } \\
\text { administered } \\
\text { survey (no } \\
\text { information } \\
\text { on translated } \\
\text { instrument or } \\
\text { bilingual } \\
\text { interviewers) }\end{array}$ & $\begin{array}{l}\text { Cross- } \\
\text { sectional }\end{array}$ & $\begin{array}{l}13,158 \\
(100 \% \\
\text { foreign- } \\
\text { born) }\end{array}$ & $\begin{array}{l}\text { Smoking } \\
\text { prevalence with } \\
\text { different lengths of } \\
\text { stay (3 categories) }\end{array}$ & $\begin{array}{l}\text { Descriptive } \\
\text { analysis Chi- } \\
\text { square-test Ana- } \\
\text { lysis stratified by } \\
\text { gender, age and } \\
\text { education }\end{array}$ & $\begin{array}{l}\text { Cross-section } \\
\text { design, very small } \\
\text { number of smokers } \\
\text { aged } 65 \text { years and } \\
\text { older, since survey } \\
\text { is carried out on } \\
\text { household level, } \\
\text { 'cluster effect' }\end{array}$ \\
\hline
\end{tabular}


24 Nierkens, de Vries, Stronks [79]

25 Vedøy [80]
2006 in the To assess smoking Turkish, Netherlands prevalence and its Moroccan, socioeconomic gradients among three immigrant populations

Surinamese
immigrants
(country of birth
and parents'
and parents country of birth)

participation in

survey is

cannot be ruled

obligatory)

Data source:

German

smoking patterns

in Germany, microcensus

(annual

Interviewer- Cross-

12,288 (59\% Smoking

admini

born) first- and second-

(translated

duration of stay

naturalization +

countrywide

census including

instrument,

households,

information

participation in

on bilingual

survey is

obligatory)

Data sources: (1)

SUNSET study

nterviewer-

Surinamese in the survey

Netherlands: Study (translated

on Ethnicity and instrument

Health), general bilingual

healh

interviewer)

questionnaire

carried out by the

Munisipal Health

Organisation

Amsterdam

(population

surveys where

samples were

drawn from

municipal

population

register)

2013 in
Norway

To investigate the

association

Data source:

HUBRO (Oslo

Turkish, Iranian,

Pakistani,

Health Study) and

Self-

administered
survey
(translated

education and

Lankan

(population sur-

instrument,

and to examine if (country of birth)

veys where sam- no

associations fit the

pattern predicted

by the model of

information

from municipal

information

population register; of bilingual

citizens born in interviewers)

1940, 1941, 1955,

1960 and 1970)

prevalence among

generation immi-

grants and with

out

Descriptive Cross-section

design, partially

square-test Ana- very small number

ysis stratified by of smokers after

generation immi- $\quad$ level, 'cluster effect'

grants (3

cannot be ruled

out

Cross-section

$\begin{array}{lll}\text { current smokers } & \text { analysis } & \text { design, self- } \\ \text { and former } & \text { Percentages } & \text { reported smokin }\end{array}$

smokers by with 95\% status, no figures

gender, age and confidence about exact re-

genducation and and and and

intervals and sponse rates of

Turkish and Moroc-

can sample (sele

tion bias cannot

Cross-section

design, self-

reported smoking

status, low re-

sponse rates

among immigrants

(selection bias can-

not be ruled out)

selection caused

by variations in im-

migration history

might have influ-

enced differences

between immi-

grant groups 
Table 4 Methodological quality assessment of the articles included in the review (Continued)

\begin{tabular}{|c|c|c|c|c|c|c|c|c|c|c|c|}
\hline 26 & $\begin{array}{l}\text { White, Harland, } \\
\text { Bhopal, Unwin, } \\
\text { Alberti [81] }\end{array}$ & 2001 in UK & $\begin{array}{l}\text { To present } \\
\text { representative data } \\
\text { on smoking }\end{array}$ & $\begin{array}{l}\text { Chinese } \\
\text { immigrants } \\
\text { (probably self- } \\
\text { identification, not } \\
\text { further specified) }\end{array}$ & $\begin{array}{l}\text { First, name analysis } \\
\text { of Health Services } \\
\text { register; second, } \\
\text { publicity aimed at } \\
\text { Chinese } \\
\text { community; third, } \\
\text { respondents } \\
\text { identified other } \\
\text { Chinese residents } \\
\text { known to them }\end{array}$ & $\begin{array}{l}\text { Party self- } \\
\text { administered, } \\
\text { partly } \\
\text { interviewer- } \\
\text { administered } \\
\text { survey (trans- } \\
\text { lated instru- } \\
\text { ment, bilin- } \\
\text { gual } \\
\text { interviewer) }\end{array}$ & $\begin{array}{l}\text { Cross- } \\
\text { sectional }\end{array}$ & $\begin{array}{l}380(100 \% \\
\text { foreign- } \\
\text { born) }\end{array}$ & $\begin{array}{l}\text { Percentage of } \\
\text { current, ex, and } \\
\text { never smokers by } \\
\text { gender, age, social } \\
\text { class, marital status }\end{array}$ & $\begin{array}{l}\text { Descriptive } \\
\text { analysis Chi- } \\
\text { square-test, } \\
\text { Mantel-Haenszel } \\
\text { test Age- } \\
\text { standardisation } \\
\text { (direct method) }\end{array}$ & $\begin{array}{l}\text { Due to the used } \\
\text { methodology } \\
\text { impossible to } \\
\text { provide an } \\
\text { accurate response } \\
\text { rate, findings may } \\
\text { not be } \\
\text { representative for } \\
\text { Chinese who } \\
\text { reside in other } \\
\text { areas of the UK, } \\
\text { very small sample } \\
\text { size, more detailed } \\
\text { information } \\
\text { needed on types } \\
\text { and daily patterns, } \\
\text { knowledge and } \\
\text { attitude towards } \\
\text { smoking }\end{array}$ \\
\hline 27 & $\begin{array}{l}\text { Girgis, Adily, } \\
\text { Velasco, Garden, } \\
\text { Zwar, Jalaludin, } \\
\text { Ward [82] }\end{array}$ & $\begin{array}{l}2009 \text { in } \\
\text { Australia }\end{array}$ & $\begin{array}{l}\text { To determine } \\
\text { associations of } \\
\text { tobacco use and } \\
\text { tobacco control } \\
\text { indicators }\end{array}$ & $\begin{array}{l}\text { Arab immigrants } \\
\text { (probably self- } \\
\text { identification, not } \\
\text { further specified) }\end{array}$ & $\begin{array}{l}\text { Recruitment of } \\
\text { Arab immigrants } \\
\text { (18-65 years) via } \\
\text { Arab speaking } \\
\text { general } \\
\text { practitioners }\end{array}$ & $\begin{array}{l}\text { Self- } \\
\text { administered } \\
\text { survey } \\
\text { (translated } \\
\text { instrument, } \\
\text { no } \\
\text { information } \\
\text { on presence } \\
\text { of bilingual } \\
\text { interviewers) }\end{array}$ & $\begin{array}{l}\text { Cross- } \\
\text { sectional }\end{array}$ & $\begin{array}{l}1,371(100 \% \\
\text { foreign- } \\
\text { born) }\end{array}$ & $\begin{array}{l}\text { DV: current smoker } \\
\text { vs. non-smoker, re- } \\
\text { call of cessation } \\
\text { advice vs. no recall, } \\
\text { nicotine depend- } \\
\text { ence (scale), readi- } \\
\text { ness to quit (scale) } \\
\text { IV: age, gender, } \\
\text { education, employ- } \\
\text { ment, marital sta- } \\
\text { tus, health status }\end{array}$ & $\begin{array}{l}\text { Logistic } \\
\text { regressions \& } \\
\text { linear } \\
\text { regressions }\end{array}$ & $\begin{array}{l}\text { Selection bias due } \\
\text { to sampling } \\
\text { procedure via } \\
\text { general } \\
\text { practitioners (low } \\
\text { response rate), self- } \\
\text { reported tobacco } \\
\text { use }\end{array}$ \\
\hline
\end{tabular}




\section{Strengths and limitations of the review}

This review combines the concept of acculturation and the model of the 'smoking epidemic' for the research on smoking in immigrants. So far, studies focused on either of both aspects. Linking the health transition in terms of the 'smoking epidemic' to the acculturation process is the major strength of this review.

Besides this strength, the review has some limitations: first, factors associated with smoking were dichotomised only (e.g. high vs. low, long vs. short - see Table 2). This was done in order to better illustrate the main findings. Such a simplification leads to a loss of information and to a possible misclassification as specific definitions and measurements of the variables (e.g. long vs. short length of stay) are likely to vary between the studies. Second, 19 of 27 studies were conducted in the USA and most focused on Asian immigrants. This might bias the findings of the review towards this immigrant group or towards US immigrants in general. At the same time it reveals the need to further investigate factors associated with smoking among immigrants in countries other than the USA. Third, the retrieval procedure was performed by using the database PubMed only. Thus, it cannot be excluded that additional articles on the topic under study appeared in journals not listed in the database. However, as the database covers a large number of journals from the life sciences and biomedicine, it is not likely that a substantial number of papers on smoking behaviour among immigrants have been missed.

\section{Conclusion}

\section{Implications for future research}

While 11 of 27 studies stratified their analysis by gender, seven studies only adjusted for gender. Future studies should not only appreciate gender differences in smoking behaviour by adjusting for gender, but explicitly assess gender as a potential modifying variable. This might also help to further explore the 'immigrant paradox' where higher acculturated women are more likely to participate in unhealthy behaviours. Moreover, measures of acculturation should not just be unidimensional, with either a weak or a strong orientation towards the culture of the host country. As immigrants do not have to give up their traditional culture in the process of acculturation, unidimensional measures do not satisfactorily reflect the inherent multidimensionality of acculturation. Such multi-item scales should furthermore be based on theoretical or conceptual work. This could promote a more direct approach to studying the process of acculturation (rather than relying on proxy measures) and thus help to better understand the association between acculturation and health behaviour. Additionally, information bias might be minimised.
All studies we could include in this review were crosssectional. As acculturation is a process, only longitudinal studies will properly track how changes in acculturation affect health-related behaviour over time. This also applies to other variables which may have an effect on smoking such as education or economic factors; they are time-variant as well and therefore prone to change with increasing duration of stay in the host country. Besides, not only the situation in the host country influences the smoking behaviour among immigrants, the process of immigration itself and the situation in the countries of origin - and thus the context of migration - may have an impact on health behaviour. Consequently, future studies should focus on a life-course perspective to reveal mechanisms and determinants responsible for uptake, maintenance and cessation of smoking $[53,54]$.

\section{Implications for prevention and health promotion}

Health professionals need to be aware of the patterns of smoking among immigrants identified in this review and adapt existing health promotion programs or plan and initiate new programs accordingly. In particular, they need to employ different strategies for immigrant men and women. Programs for male immigrants should aim to further decrease smoking prevalence, whereas programs addressing immigrant women should aim at preventing smoking initiation. Immigrants of both sexes need to be made aware of the social and cultural forces that operate during the process of acculturation and may affect their smoking behaviour. As smoking and acculturation are not only individual but also social and group phenomena, key persons from immigrant communities should be involved in implementing strategies in their communities, settings, and networks [55]. Thus, knowing the factors associated with smoking among immigrants is only the first step towards its prevention.

\section{Competing interests}

The authors declare that they have no competing interests.

\section{Authors' contribution}

All authors specified the focus of the review and determined the inclusion and exclusion criteria. OR supervised and coordinated the review. JL and KR performed it and drafted the manuscript. All authors made substantial contributions to the interpretation of the results, reviewed the submitted manuscript and approved the manuscript for submission.

\section{Acknowledgements}

This work was partly supported by a Young Researcher's Starting Grant from Bielefeld University.

The authors would like to thank Petra Kolip for helpful comments and advice on an earlier version of this paper.

Received: 25 August 2014 Accepted: 28 March 2015

Published online: 16 April 2015

\section{References}

1. Doll R, Peto R, Boreham J, Sutherland I. Mortality in relation to smoking: 50 years' observations on male British doctors. BMJ. 2004;328(7455):1519-28. 
2. Vineis $P$, Alavanja $M$, Buffler $P$, Fontham $E$, Franceschi $S$, Gao $Y T$, et al. Tobacco and cancer: recent epidemiological evidence. J Natl Cancer Inst. 2004;96(2):99-106.

3. Burns DM. Epidemiology of smoking-induced cardiovascular disease. Prog Cardiovasc Dis. 2003;46(1):11-29.

4. Shinton R, Beevers G. Meta-analysis of relation between cigarette smoking and stroke. BMJ. 1989;298(6676):789-94.

5. Mackenbach JP, Karanikolos M, McKee M. The unequal health of Europeans: successes and failures of policies. Lancet. 2013;381(9872):1125-34.

6. Branstetter SA, Blosnich J, Dino G, Nolan J, Horn K. Gender differences in cigarette smoking, social correlates and cessation among adolescents. Addict Behav. 2012;37(6):739-42.

7. Karasek D, Ahern J, Galea S. Social norms, collective efficacy, and smoking cessation in urban neighborhoods. Am J Public Health. 2012;102(2):343-51.

8. Wilson LM, Avila Tang E, Chander G, Hutton HE, Odelola OA, Elf JL, et al. Impact of tobacco control interventions on smoking initiation, cessation, and prevalence: a systematic review. J Environ Public Health. 2012;2012:961724.

9. Hiscock R, Bauld L, Amos A, Fidler JA, Munafò M. Socioeconomic status and smoking: a review. Ann N Y Acad Sci. 2012;1248:107-23.

10. Mckee SA, Sinha R, Weinberger AH, Sofuoglu M, Harrison EL, Lavery $M$, et al. Stress decreases the ability to resist smoking and potentiates smoking intensity and reward. J Psychopharmacol. 2011;25(4):490-502.

11. Christakis NA, Fowler JH. The collective dynamics of smoking in a large social network. N Engl J Med. 2008;358(21):2249-58.

12. Huisman M, Kunst AE, Mackenbach JP. Educational inequalities in smoking among men and women aged 16 years and older in 11 European countries. Tob Control. 2005;14(2):106-13.

13. Kassel JD, Stroud LR, Paronis CA. Smoking, stress, and negative affect: correlation, causation, and context across stages of smoking. Psychol Bull. 2003;129(2):270-304

14. Barbeau EM, Leavy-Sperounis A, Balbach ED. Smoking, social class, and gender: what can public health learn from the tobacco industry about disparities in smoking? Tob Control. 2004;13(2):115-20.

15. Waldron I. Patterns and causes of gender differences in smoking. Soc Sci Med. 1991;32(9):989-1005.

16. Lopez AD, Collishaw NE, Piha T. A descriptive model of the cigarette epidemic in developed countries. Tob Control. 1994;3(3):242-47.

17. Thun M, Peto R, Boreham J, Lopez AD. Stages of the cigarette epidemic on entering its second century. Tob Control. 2012;21(2):96-101.

18. Narain JP, Sinha DN. Tobacco epidemic in South-East Asia region: challenges and progress in its control. Indian J Public Health. 2011;55(3):151-4.

19. Singh PN, Yel D, Sin S, Khieng S, Lopez J, Job J, et al. Tobacco use among adults in Cambodia: evidence for a tobacco epidemic among women. Bull World Health Organ. 2009;87(12):905-12

20. Ward KD, Eissenberg T, Rastam S, Asfar T, Mzayek F, Fouad MF, et al. The tobacco epidemic in Syria. Tob Control. 2006;15 Suppl 1:i24-9.

21. Pampel FC. Patterns of tobacco use in the early epidemic stages: Malawi and Zambia, 2000-2002. Am J Public Health. 2005;95(6):1009-15.

22. Chen ZM, Xu Z, Collins R, Li WX, Peto R. Early health effects of the emerging tobacco epidemic in China. A 16-year prospective study. JAMA. 1997;278(18):1500-4.

23. Razum O, Twardella D. Time travel with Oliver Twist - towards an explanation for a paradoxically low mortality among recent immigrants. Trop Med Int Health. 2002;7(1):4-10.

24. Rudmin FW. Catalogue of Acculturation Constructs: Descriptions of 126 Taxonomies, 1918-2003. In: Lonner WJ, Dinnel DL, Hayes SA, Sattler DN editors. Online Readings in Psychology and Culture (Unit 8, Chapter 8). Bellingham, Washington DC: Center for Cross-Cultural Research, Western Washington University; 2003.

25. Berry JW. Immigration, acculturation, and adaptation. Appl Psychol - Int Rev. 1997;46(1):5-34.

26. Schwartz SJ, Unger JB, Zamboanga BL, Szapocznik J. Rethinking the concept of acculturation: implications for theory and research. Am Psychol. 2010;65(4):237-51.

27. Cabassa LJ. Measuring acculturation: where we are and where we need to go. Hispanic J Behav Sci. 2003;25(2):127-46.

28. Chakraborty BM, Chakraborty R. Concept, measurement and use of acculturation in health and disease risk studies. Coll Antropol. 2010;34(4):1179-91.
29. Abraído-Lanza AF, Armbrister AN, Flórez KR, Aguirre AN. Toward a theory-driven model of acculturation in public health research. Am J Public Health. 2006;96(8):1342-6.

30. Chun KM, Organista PB, Marin G. Acculturation: Advances in Theory, Measurement, and Applied Research. Washington DC: American Psychological Association; 2002.

31. Schaefer SE, Salazar M, Bruhn C, Saviano D, Boushey C, van Loan MD. Influence of race, acculturation, and socioeconomic status on tendency toward overweight in Asian-American and Mexican-American early adolescent females. J Immigr Minor Health. 2009;11(3):188-97.

32. Lara M, Gamboa C, Kahramanian MI, Morales LS, Bautista DE. Acculturation and Latino health in the United States: a review of the literature and its sociopolitical context. Annu Rev Public Health. 2005;26:367-97.

33. Kandula NR, Kersey M, Lurie N. Assuring the health of immigrants: what the leading health indicators tell us. Annu Rev Public Health. 2004;25:357-76.

34. Salant T, Lauderdale DS. Measuring culture: a critical review of acculturation and health in Asian immigrant populations. Soc Sc Med. 2003;57(1):71-90.

35. Lee S, Chen L, He X, Miller MJ, Juon HS. A cluster analytic examination of acculturation and health status among Asian Americans in the Washington DC metropolitan area, United States. Soc Sci Med. 2013;96:17-23.

36. Lim JW, Yi J, Zebrack B. Acculturation, social support, and quality of life for Korean immigrant breast and gynecological cancer survivors. Ethn Health. 2008;13(3):243-60.

37. Abraído-Lanza AF, Chao MT, Flórez KR. Do healthy behaviors decline with greater acculturation? Implications for the Latino mortality paradox. Soc Sci Med. 2005;61(6):1243-55

38. Van Wieren AJ, Roberts MB, Arellano N, Feller ER, Diaz JA. Acculturation and cardiovascular behaviors among Latinos in California by country/region of origin. J Immigr Minor Health. 2011;13(6):975-81.

39. Pérez-Stable EJ, Ramirez A, Villareal R, Talavera GA, Trapido E, Suarez L, et al. Cigarette smoking behavior among US Latino men and women from different countries of origin. Am J Public Health. 2001;91(9):1424-30.

40. Tang H, Shimizu R, Chen Jr MS. English language proficiency and smoking prevalence among California's Asian Americans. Cancer. 2005;104(12 Suppl):2982-8.

41. Kim SS, Ziedonis D, Chen KW. Tobacco use and dependence in Asian Americans: a review of the literature. Nicotine Tob Res. 2007;9(2):169-84.

42. Zhang J, Wang Z. Factors associated with smoking in Asian American adults: a systematic review. Nicotine Tob Res. 2008;10(5):791-801.

43. Bethel JW, Schenker MB. Acculturation and smoking patterns among Hispanics: a review. Am J Prev Med. 2005;29(2):143-8.

44. Choi S, Rankin S, Stewart A, Oka R. Effects of acculturation on smoking behavior in Asian Americans: a meta-analysis. J Cardiovasc Nurs. 2008;23(1):67-73.

45. Marin G, Perez-Stable EJ, Marin BV. Cigarette smoking among San Francisco Hispanics: the role of acculturation and gender. Am J Public Health. 1989;79(2):196-8.

46. Bhopal R, Vettini A, Hunt S, Wiebe S, Hanna L, Amos A. Review of prevalence data in, and evaluation of methods for cross cultural adaptation of, UK surveys on tobacco and alcohol in ethnic minority groups. BMJ. 2004;328(7431):76.

47. Brzoska P. Psychometrically Relevant Differences between Source and Migrant Populations. Frankfurt am Main: Peter Lang; 2014.

48. Peto R, Lopez AD. Future Worldwide Health Effects of Current Smoking Patterns. In: Koop CE, Pearson CE, Schwarz MR, editors. Critical Issues in Global Health. San Francisco: Jossey-Bass; 2001. p. 154-61.

49. Landrine $\mathrm{H}$, Klonoff EA. Culture change and ethnic-minority health behavior: an operant theory of acculturation. J Behav Med. 2004;27(6):527-55.

50. Corral I, Landrine H. Acculturation and ethnic-minority health behavior: a test of the operant model. Health Psychol. 2008;27(6):737-45.

51. Acevedo-Garcia D, Pan J, Jun HJ, Osypuk TL, Emmons KM. The effect of immigrant generation on smoking. Soc Sci Med. 2005;61(6):1223-42.

52. Constantine ML, Adejoro OO, D'Silva J, Rockwood TH, Schillo BA. Evaluation of use of stage of tobacco epidemic to predict post-immigration smoking behaviors. Nicotine Tob Res. 2013;15(11):1910-7.

53. Spallek J, Zeeb H, Razum O. What do we have to know from migrants' past exposures to understand their health status? A life course approach. Emerg Themes Epidemiol. 2011;8(1):6.

54. Schooling M, Kuh D. A Life Course Perspective on Women's Health Behaviours. In: Kuh D, Hardy R, editors. A Life Course Approach to Women's Health. Oxford: Oxford University Press; 2002. p. 279-303. 
55. Poonia J. Smoking Cessation and Ethnic Minority Communities. Findings of Qualitative Research Project with Turkish, Polish, and Somalian Communities in London. London, England: NHS Commissioning Support for London; 2009.

56. Constantine ML, Rockwood TH, Schillo BA, Alesci N, Foldes SS, Phan T, et al. Exploring the relationship between acculturation and smoking behavior within four Southeast Asian communities of Minnesota. Nicotine Tob Res. 2010;12(7):715-23.

57. Hu SS, Pallonen UE, Meshack AF. The impact of immigration status on tobacco use among Chinese-American adults in Texas. J Immigr Minor Health. 2010;12(2):206-14.

58. Al-Omari $\mathrm{H}$, Scheibmeir M. Arab Americans' acculturation and tobacco smoking. J Transcult Nurs. 2009;20(2):227-33.

59. Stoddard P. Risk of smoking initiation among Mexican immigrants before and after immigration to the United States. Soc Sci Med. 2009;69(1):94-100.

60. Maxwell AE, Garcia GM, Berman BA. Understanding tobacco use among Filipino American men. Nicotine Tob Res. 2007;9(7):769-76.

61. An N, Cochran SD, Mays VM, McCarthy WJ. Influence of American acculturation on cigarette smoking behaviors among Asian American subpopulations in California. Nicotine Tob Res. 2008;10(4):579-87.

62. Maxwell AE, Bernaards CA, McCarthy WJ. Smoking prevalence and correlates among Chinese- and Filipino-american adults: findings from the 2001 California health interview survey. Prev Med. 2005;41(2):693-9.

63. Rahman MM, Luong NT, Divan HA, Jesser C, Golz SD, Thirumalai K, et al. Prevalence and predictors of smoking behavior among Vietnamese men living in California. Nicotine Tob Res. 2005;7(1):103-9.

64. Wilkinson AV, Spitz MR, Strom SS, Prokhorov AV, Barcenas CH, Cao Y, et al. Effects of nativity, age at migration, and acculturation on smoking among adult Houston residents of Mexican descent. Am J Public Health. 2005;95(6)):1043-9.

65. Hofstetter CR, Hovell MF, Lee J, Zakarian J, Park H, Paik HY, et al. Tobacco use and acculturation among Californians of Korean descent: a behavioral epidemiological analysis. Nicotine Tob Res. 2004;6(3):481-9.

66. Shelley D, Fahs M, Scheinmann R, Swain S, Qu J, Burton D. Acculturation and tobacco use among Chinese Americans. Am J Public Health. 2004;94(2):300-7.

67. Fu SS, Ma GX, Tu XM, Siu PT, Metlay JP. Cigarette smoking among Chinese Americans and the influence of linguistic acculturation. Nicotine Tob Res. 2003;5(6):803-11.

68. Juon HS, Kim M, Han H, Ryu JP, Han W. Acculturation and cigarette smoking among Korean American men. Yonsei Med J. 2003;44(5):875-82.

69. Ma GX, Shive S, Tan Y, Toubbeh J. Prevalence and predictors of tobacco use among Asian Americans in the Delaware Valley region. Am J Public Health. 2002;92(6):1013-20.

70. Yu ES, Chen EH, Kim KK, Abdulrahim S. Smoking among Chinese Americans: behavior, knowledge, and beliefs. Am J Public Health. 2002;92(6):1007-12.

71. Kim KK, Yu ES, Chen EH, Kim J, Brintnall R, Vance S. Smoking behavior, knowledge, and beliefs among Korean Americans. Cancer Pract. 2000;8(5):223-30.

72. Shankar S, Gutierrez-Mohamed ML, Alberg AJ. Cigarette smoking among immigrant Salvadoreans in Washington, DC: behaviors, attitudes, and beliefs. Addict Behav. 2000;25(2):275-81.

73. King G, Polednak AP, Bendel R, Hovey D. Cigarette smoking among native and foreign-born African Americans. Ann Epidemiol. 1999;9(4):236-44.

74. Wiecha JM, Lee V, Hodgkins J. Patterns of smoking, risk factors for smoking, and smoking cessation among Vietnamese men in Massachusetts (United States). Tob Control. 1998;7(1):27-34.

75. Hyman I, Fenta H, Noh S. Gender and the smoking behaviour of Ethiopian immigrants in Toronto. Chronic Dis Can. 2008;28(4):121-7.

76. Kabir Z, Clarke V, Keogan S, Currie LM, Zatonski W, Clancy L. Smoking characteristics of Polish immigrants in Dublin. BMC Public Health. 2008;8:428.

77. Reiss K, Spallek J, Razum O. 'Imported risk' or 'health transition'? smoking prevalence among ethnic german immigrants from the former soviet union by duration of stay in germany - analysis of microcensus data. Int J Equity Health. 2010;9:15.

78. Reeske A, Spallek J, Razum O. Changes in smoking prevalence among first- and second-generation Turkish migrants in Germany - an analysis of the 2005 Microcensus. Int J Equity Health. 2009;8:26.

79. Nierkens $V$, de Vries H, Stronks K. Smoking in immigrants: do socioeconomic gradients follow the pattern expected from the tobacco epidemic? Tob Control. 2006;15(5):385-91.
80. Vedøy TF. The role of education for current, former and never-smoking among non-western immigrants in Norway. Does the pattern fit the model of the cigarette epidemic? Ethn Health. 2013;18(2):190-210.

81. White M, Harland JO, Bhopal RS, Unwin N, Alberti KG. Smoking and alcohol consumption in a UK Chinese population. Public Health. 2001;115(1):62-9.

82. Girgis S, Adily A, Velasco MJ, Garden FL, Zwar NA, Jalaludin BB, et al. Smoking patterns and readiness to quit-a study of the Australian Arabic community. Aust Fam Physician. 2009;38(3):154-61.

\section{Submit your next manuscript to BioMed Central and take full advantage of:}

- Convenient online submission

- Thorough peer review

- No space constraints or color figure charges

- Immediate publication on acceptance

- Inclusion in PubMed, CAS, Scopus and Google Scholar

- Research which is freely available for redistribution 